\title{
Inflammation and its role in age-related macular degeneration
}

\author{
Anu Kauppinen ${ }^{1,2}$ (1) Jussi J. Paterno ${ }^{3} \cdot$ Janusz Blasiak $^{4} \cdot$ Antero Salminen $^{5} \cdot$ Kai Kaarniranta ${ }^{2,3}$
}

Received: 4 November 2015/Revised: 21 January 2016/Accepted: 25 January 2016/Published online: 6 February 2016

(C) The Author(s) 2016. This article is published with open access at Springerlink.com

\begin{abstract}
Inflammation is a cellular response to factors that challenge the homeostasis of cells and tissues. Cellassociated and soluble pattern-recognition receptors, e.g. Toll-like receptors, inflammasome receptors, and complement components initiate complex cellular cascades by recognizing or sensing different pathogen and damage-associated molecular patterns, respectively. Cytokines and chemokines represent alarm messages for leukocytes and once activated, these cells travel long distances to targeted inflamed tissues. Although it is a crucial survival mechanism, prolonged inflammation is detrimental and participates in numerous chronic age-related diseases. This article will review the onset of inflammation and link its functions to the pathogenesis of age-related macular degeneration (AMD), which is the leading cause of severe vision loss in aged individuals in the developed countries. In this progressive disease, degeneration of the retinal pigment epithelium (RPE) results in the death of photoreceptors, leading to a loss of central vision. The RPE is prone to oxidative stress, a factor that together with deteriorating functionality, e.g. decreased intracellular
\end{abstract}

Anu Kauppinen

anu.kauppinen@uef.fi

1 Faculty of Health Sciences, School of Pharmacy, University of Eastern Finland, P.O. Box 1627, 70211 Kuopio, Finland

2 Department of Ophthalmology, Kuopio University Hospital, Kuopio, Finland

3 Department of Ophthalmology, Institute of Clinical Medicine, University of Eastern Finland, Kuopio, Finland

4 Department of Molecular Genetics, Faculty of Biology and Environmental Protection, University of Lodz, Lodz, Poland

5 Department of Neurology, Institute of Clinical Medicine, University of Eastern Finland, Kuopio, Finland recycling and degradation due to attenuated heterophagy/ autophagy, induces inflammation. In the early phases, accumulation of intracellular lipofuscin in the RPE and extracellular drusen between RPE cells and Bruch's membrane can be clinically detected. Subsequently, in dry (atrophic) AMD there is geographic atrophy with discrete areas of RPE loss whereas in the wet (exudative) form there is neovascularization penetrating from the choroid to retinal layers. Elevations in levels of local and systemic biomarkers indicate that chronic inflammation is involved in the pathogenesis of both disease forms.

Keywords Signaling - Aging - Immune system · NLRP3 $\cdot$ Eye $\cdot$ Retina

\section{Introduction}

\section{Overview of inflammation}

Inflammation is a rapid response mounted by the cell to a threat of imminent danger. Inflammation is intended to eliminate foreign or damaged material, and to signal to other cells that there is a danger in order that they can initiate a broader immune response. Later, it should initiate tissue recovery. Monocyte-derived phagocytizing innate immune cells of myeloid origin which are present in many tissues, such as macrophages, microglia, and Kupffer cells, play a key role in the initiation of inflammation and recently, the capacity of granulocytes to initiate inflammation has been recognized [1]. Also other cells are involved in the induction of inflammation; e.g. epithelial cells which until recently were thought mainly to provide a mechanical barrier [2]. Inflammation can be induced by a wide variety of signals, ranging from microbes and other 
4Fig. 1 a A schematic transverse section through the human eyeball. The macula is located in the posterior pole of the eye. In the center of the macula, a shallow depression in the retina (the fovea) marks the area with the highest visual acuity. Light enters the eye and bends to the sensory retina in the fovea by passing through the transparent media including cornea, lens, and the vitreous body. The sensory retina converts light into nerve impulses, processes the information, and sends it along the visual pathway to the visual cortex. b A normal human retina. A colored photograph of the fundus from the left eye of a healthy subject. The macula is located in the center of the retina. c A cross-section of the normal macula. An OCT scan through the fovea of the healthy left eye reveals the normal organization of the retinal layers. Normal anatomy of the fovea is important for accurate central vision. Modern OCT is an important in vivo tool for ophthalmologists since it allows them to monitor different pathologies non-invasively in this important but tiny and cell-dense location. d A fundus photograph from the left eye of an individual with dry AMD. This demonstrates the presence of numerous yellow deposits, known as drusen, in the central macula. e A cross-section of the macula from an individual with dry AMD. The OCT scan through the fovea of the left eye shows three drusen under the RPE layer. This eye would be expected to suffer from image distortion, as central drusen are prone to reshape the normal foveal pit. Large drusen are associated with decreased visual acuity and disruption of energy homeostasis in the retina. $\mathbf{f}$ A fundus photograph from the right eye of an individual with wet AMD. Significant macular edema and exudates together with foveal hemorrhage occur but only small sparse drusen are present centrally. $\mathbf{g}$ A cross-section from the macula in the right eye of an individual with wet AMD. An OCT scan through the location of the fovea shows the formation of intraretinal fluid cysts in the fovea. Edema causes the foveal pit to disappear. The local retinal swelling in wet AMD is due to the leaky, abnormal vessels sprouting from the underlying choroid. Intraretinal edema disrupts the normal retinal layer organization and leads to a retinal dysfunction. The OCT scan reveals also a potential hemorrhage and fibrotic lesion development in the fovea. This is another typical finding in wet AMD, likely to result in a permanent central visual field loss, if left untreated. $A M D$ agerelated macular degeneration, $O C T$ optical coherence tomography, $R P E$ retinal pigment epithelium

foreign material to mechanical tissue injury and autoantigens. A threat becomes recognized by pattern-recognition receptors (PRRs). From the short-term point of view, inflammation is highly advantageous, e.g. when it is a response to microbial infection or mechanical injuries, but long-term inflammation is detrimental. Prolonged lowlevel inflammation has been linked with the development of various chronic conditions, such as cancer, diabetes, autoimmune diseases, as well as several obesity-related and neurodegenerative diseases [3, 4].

\section{Age-related macular degeneration (AMD)}

AMD is a progressive eye disease that has been linked with several pathological factors, i.e. chronic oxidative stress, autophagy decline, and inflammation [5-10]. It is the most common reason for irreversible vision impairment in aged individuals in the developed countries where refractive errors, cataract, and glaucoma are now effi-
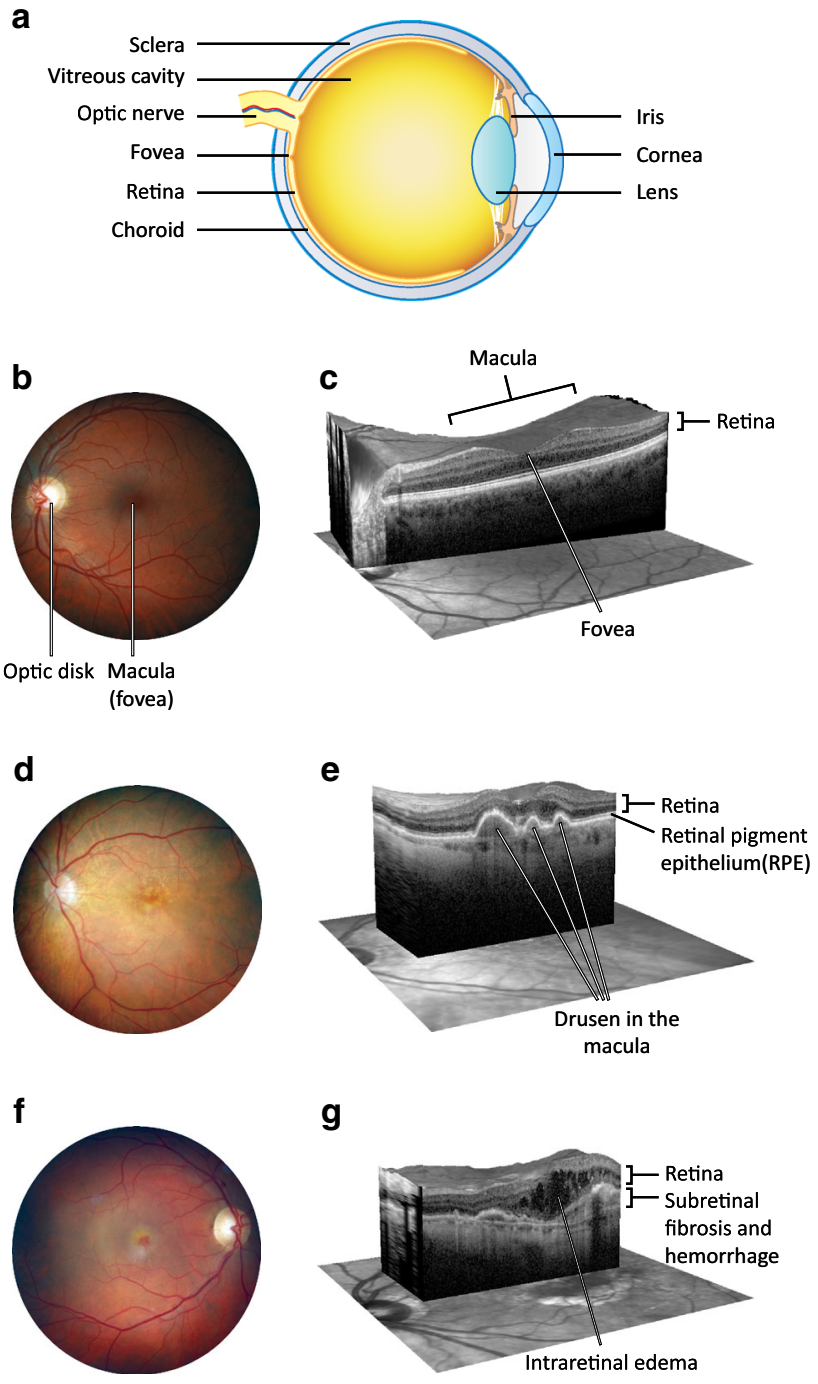

ciently treated. Early AMD is usually asymptomatic, although retinal pigment epithelium (RPE) mottling and extracellular drusen deposits between RPE cells and Bruch's membrane can be clinically detected in the central posterior pole of the eye [6] (Fig. 1). Bruch's membrane is a five-layered sheet lying over the highly vascularized choroid, and it makes contacts with both vascular endothelium and RPE. The accumulation of drusen increases an individual's risk of developing advanced AMD. AMD is subdivided into two types, dry and wet AMD forms, also known as geographic atrophy and exudative AMD, respectively (Fig. 1). In wet AMD, the RPE produces excessive amounts of vascular endothelial growth factor (VEGF), and this contributes to the breakdown of the blood-retinal barrier and sprouting of fragile blood vessels from the choroid through Bruch's membrane into the retina in a process called neovascularization. Leakage of blood from these abnormal vessels 
causes oedema and an acute loss of vision [11, 12]. As the world's population ages, the global burden of AMD will increase, posing a huge burden on the health care system [13-15]. Therefore, efforts have been made to resolve the pathophysiology of AMD and to develop effective treatments. During the recent decade, the management of the wet AMD has advanced dramatically due to the arrival of anti-VEGF therapies [16]. Currently, there are several different forms of effective intravitreal treatment available for decelerating the progress of wet AMD but unfortunately no such advances have been made in the treatment of dry AMD, the disease type that accounts for the majority (up to $90 \%$ ) of cases [17-20]. A reduction of intracellular inflammation in conjunction with the prevention of RPE and photoreceptor loss all have central roles in programmes developing novel therapy options for AMD [21].

\section{Retinal pigment epithelium in the pathogenesis of AMD}

The RPE, a single-cell layer at the posterior part of the eye plays a significant role in the pathogenesis of AMD. RPE cells are responsible for many tasks in the eye including maintaining the functionality of the overlying photoreceptor cells, protection of the retina from excessive light, formation of blood-retinal barrier in conjunction with the vascular endothelium, and immune defence of the central retina (macula) [22, 23]. A functional degeneration of the RPE results in impaired maintenance of sensory retina, which contributes to the vision loss in advanced AMD. The photoreceptors most severely affected are located in the macular area, which is responsible for the accurate vision and colour detection and therefore AMD greatly impairs the ability of an elderly patient to lead an independent life $[6,24]$. In addition, scotomas developing in the central vision field also distort the ability to see pictures, e.g. causing a disturbance in reading, dialing numbers and facial recognition.

Due to its high metabolic activity and the associated abundant oxygen consumption, its high contents of polyunsaturated fatty acids and substantial exposure to light, the RPE is especially sensitive to excessive oxidative stress $[25,26]$. One of the major functions of RPE is the autophagic degradation of spent tips of photoreceptor outer segments (POS) in a process called heterophagy [22, 25]. Continuous ingestion of POS material by non-dividing and aging RPE cells results in the accumulation of an undegradable and autofluorescent metabolite called lipofuscin in lysosomes, which inhibits autophagy by blocking the function of lysosomal enzymes, i.e. it combines oxidative stress with retinal inflammation [10, 25, 27].

\section{Pattern-recognition receptors}

Cells recognize various endogenous and exogenous pathogen- and damage-associated molecular patterns (PAMPs and DAMPs, respectively) through their evolutionarily conserved pathogen recognition receptors (PRRs) [28]. There are several cell-associated PRRs, e.g. Toll-like receptors (TLRs), receptor for advanced glycation end products (RAGE) [29-32], NOD-like receptors [NLRs; nucleotide-binding domain, leucine-rich repeat-containing (NBD-LRR) proteins], C-type lectin receptors (CLRs), retinoic acid-inducible gene (RIG)-I-like receptors (RLRs), and cytosolic DNA sensors [28, 33, 34]. Once the receptor is activated by its ligand, it rapidly induces the activation of complex intracellular signaling pathways to produce proinflammatory mediators [34]. PRR signaling also induces the expression of co-stimulatory molecules (e.g. CD40, CD80, or CD86) contributing to the conversion of different types of $\mathrm{T}$ cells, and promoting the activation of dendritic cells such that they become capable of presenting foreign peptides to lymphocytes and trigger the activation of adaptive immunity [35].

\section{TLRs}

TLRs were the first PRRs to be discovered in the mid1990s [33]. These are transmembrane proteins capable of recognizing a multitude of extra- and intracellular pathogens [33]. TLRs $1,2,4,5,6$, and 10 are expressed on the cell surface, whereas TLRs 3, 7, 8, and 9 reside inside the cell $[34,36]$. TLRs contain a ligand-sensing leucine-rich repeat (LRR) domain, a transmembrane domain, and a cytoplasmic Toll/IL-1 receptor (TIR) domain, and the receptors function as either homo- or heterodimers $[33,36]$ (Fig. 2). Roughly, TLR signaling can be divided into MyD88-dependent pathways that result in the production of pro-inflammatory cytokines, and TRIF-dependent signaling that aims at producing type I interferons in response to viral infections [33] (Fig. 2). Although TLR signaling results in the secretion of inflammatory cytokines, chemokines, type I interferons, and antimicrobial peptides, its crosstalk with other PRRs, such as membrane-bound CLRs, and cytosolic NLRs and RLRs, is important in the regulation of immune responses. One good example of PRR collaboration is the activation of inflammasome signaling. TLR signaling produces the pro-forms of inflammasome-dependent cytokines IL-1 $\beta$ and IL-18, which remain inactive in the cytoplasm until a second signal is sensed, e.g. by NLRs, leading to the maturation and secretion of these cytokines after inflammasome assembly and caspase-1-mediated proteolysis [37]. 


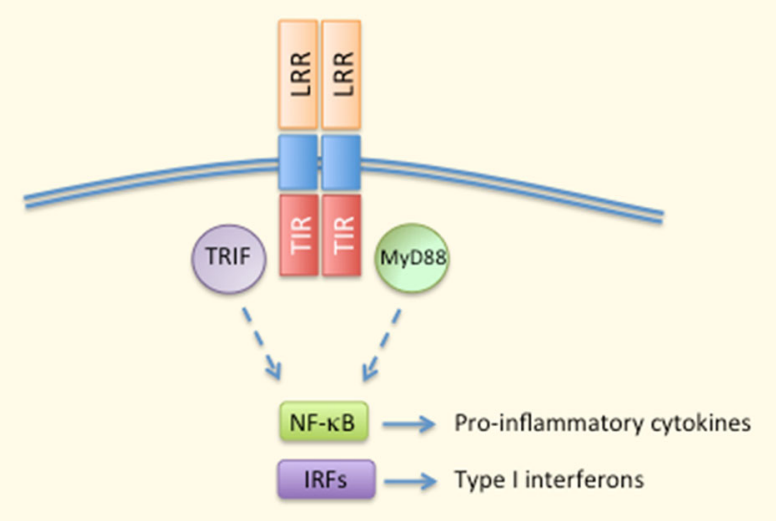

Fig. 2 Major aspects of TLR signaling. Ligand recognition by LRR domains triggers the dimerisation of TLR proteins. MyD88 and TRIF are the principal adaptor proteins interacting with intracellular TIR domains and mediating the activation of transcription factors, such as $\mathrm{NF}-\kappa \mathrm{B}$ and IRFs for the production of pro-inflammatory cytokines and type I interferons. IRFs interferon regulatory factors, $L R R$ leucine-rich repeat, $M y D 88$ myeloid differentiation-primary response gene $88, N F-\kappa B$ nuclear factor kappa B, TIR Toll/IL-1 receptor domain, TRIF TIR-domain-containing adaptor inducing IFN- $\beta$

\section{RAGE}

RAGE (receptor for advanced glycation end products) has been compared to TLRs because of its presence on the plasma membrane as well as its pro-inflammatory functions mediated through NF- $\kappa \mathrm{B}$ signaling [31]. As a member of immunoglobulin superfamily, it also promotes leukocyte recruitment to inflamed tissue by functioning as an endothelial adhesion receptor [29, 30]. Originally, RAGE was considered to be a receptor for advanced glycation end products (AGEs), non-enzymatically glycated or oxidated biomolecules [29-31]. Subsequently, also other ligands, such as those released from dying cells or injured tissue, have been observed to be recognized by RAGE [32]. Those factors include the normally nuclear high mobility group box 1 protein (HMGB1) and calcium-binding S100 proteins. Interestingly, RAGE can also be activated by $\beta$ amyloid, which is a compound closely associated with the development of neurodegenerative disorders, such as Alzheimer's disease and AMD $[32,38]$.

\section{CLRs}

C-type lectin receptors (CLRs) are calcium-dependent PRRs that were originally thought to respond only to carbohydrates [39]. Nowadays, the CLR family also includes proteins that do not necessarily sense carbohydrates, but contain one or more domains homologous to the carbohydrate recognition domains of traditional CLRs. CLRs can be divided into two types of cell-associated and one type of soluble receptors [39]. The transmembrane receptors can be further divided into group I and group II CLRs that belong to the mannose and asialoglycoprotein receptor families, respectively. The activation of CLRs induces complex intracellular signaling cascades and can interact with processes mediated by other PRRs.

\section{NLR}

To date, at least 23 human NLRs have been identified [40]. NLR proteins can be divided into four subfamilies according to their $\mathrm{N}$-terminal domains. These receptors commonly contain three main domains: (1) N-terminal acidic transactivation domain (NLRA proteins), baculoviral inhibitory repeat (BIR)-like domain (NLRB proteins), caspase recruitment domain (CARD; NLRC proteins), or pyrin domain (PYD; NLRP proteins) that either recruit adaptor, intermediary, or effector components for downstream signaling; (2) central NBD (nucleotide-binding domain) or NACHT (NAIP, CIITA, HET-E, and TP1) domain that is responsible for the activation-induced oligomerization; (3) the ligand-sensing C-terminal LRR (leucine-rich repeat) domain [41]. There is an evidence suggesting that at least nine human NLRs (NLRP 1, 2, 3, 6, 7, 12, NLRC4, NAIP5, and NOD2) are able to regulate caspase- 1 activation and IL- $1 \beta / \mathrm{IL}-18$ processing [40, 42 48], and NLRP1, NLRP3, NLRC4, and NAIP5 have been associated with the inflammasome activation in a broader sense (Fig. 3). Other NLRs exert variable functions, e.g. regulation of antigen presentation (NLRC5 and CIITA), inhibition/modulation of inflammation (NLRC3, NLRPs 6 and 12, NLRX1), and embryonic development (NLRPs 2, 5 , and 7) [49].

\section{$N L R P 3$}

At present, NLRP3 [NALP3, cryopyrin, caterpillar-like receptor 1.1 (CLR1.1), CIAS1, PYPAF1] is the best-characterized inflammasome receptor (Fig. 4). In resting cells, its expression is low at both the mRNA and protein levels, but it is induced by several priming signals, e.g. mediated by TLRs, NODs, or cytokine receptors [50]. NLRP3 has a versatile recognition capacity in that it can sense both endogenous and exogenous factors and these can be biological, chemical, or physical in their nature [37, 51]. Following the ligand sensing, NLRP3 protein changes its conformation and becomes oligomerized (Fig. 4). Thereafter, pro-caspase- 1 binds the complex through the adaptor protein ASC [52, 53]. The assembly of the active inflammasome results in the auto-activation of caspase-1, which subsequently cleaves the pro-inflammatory cytokines IL-1 $\beta$ and IL-18 into their mature and secreted forms (Fig. 4). 


\begin{tabular}{|c|c|c|c|c|c|c|}
\hline \multirow{4}{*}{ NLRs } & NLRP1 & PYD & NBD & LRR & FIIND & CARD \\
\hline & NLRP3 & PYD & NBD & LRR & & \\
\hline & NLRC4 & CARD & NBD & LRR & & \\
\hline & NAIP & BIR & BIR & BIR & NBD & LRR \\
\hline \multirow{2}{*}{$\begin{array}{c}\text { DNA } \\
\text { sensors }\end{array}$} & AlM2 & PYD & HIN & & & \\
\hline & IFI16 & PYD & HIN & HIN & & \\
\hline \multirow[t]{3}{*}{ RLR } & RIG-1 & CARD & CARD & \multicolumn{2}{|c|}{ RNA helicase } & Regulatory domain \\
\hline & ASC & PYD & CARD & & & \\
\hline & -caspase-1 & CARD & $20 \mathrm{kD}$ & ubunit & $10 \mathrm{kDa}$ & \\
\hline
\end{tabular}

Fig. 3 Pro-inflammatory inflammasomes. Four NLRs, two DNA sensors, and an RLR are currently the most well-known inflammasomes that promote inflammation by resulting in the release of inflammatory mediators. Receptors lacking the CARD domain are dependent on the adaptor protein ASC for their interaction with procaspase 1 , which becomes activated by autocleavage into 20 and $10 \mathrm{kDa}$ subunits by the complex assembly
Fig. 4 Overview of the NLRP3 inflammasome. Ligand recognition through LRR domains results in a conformational change and oligomerization of NLRP3 receptor proteins $(\mathbf{a})$. Thereafter, the adaptor protein ASC binds NLRP3 by PYDPYD interactions (b). Binding of pro-caspase-1 to ASC through CASP-CASP interactions promotes autocleavage and thereby activation of the caspase-1 enzyme (c). Finally, caspase-1 cleaves the pro-inflammatory cytokines IL- $1 \beta$ and IL-18 into their mature and secreted forms (d)
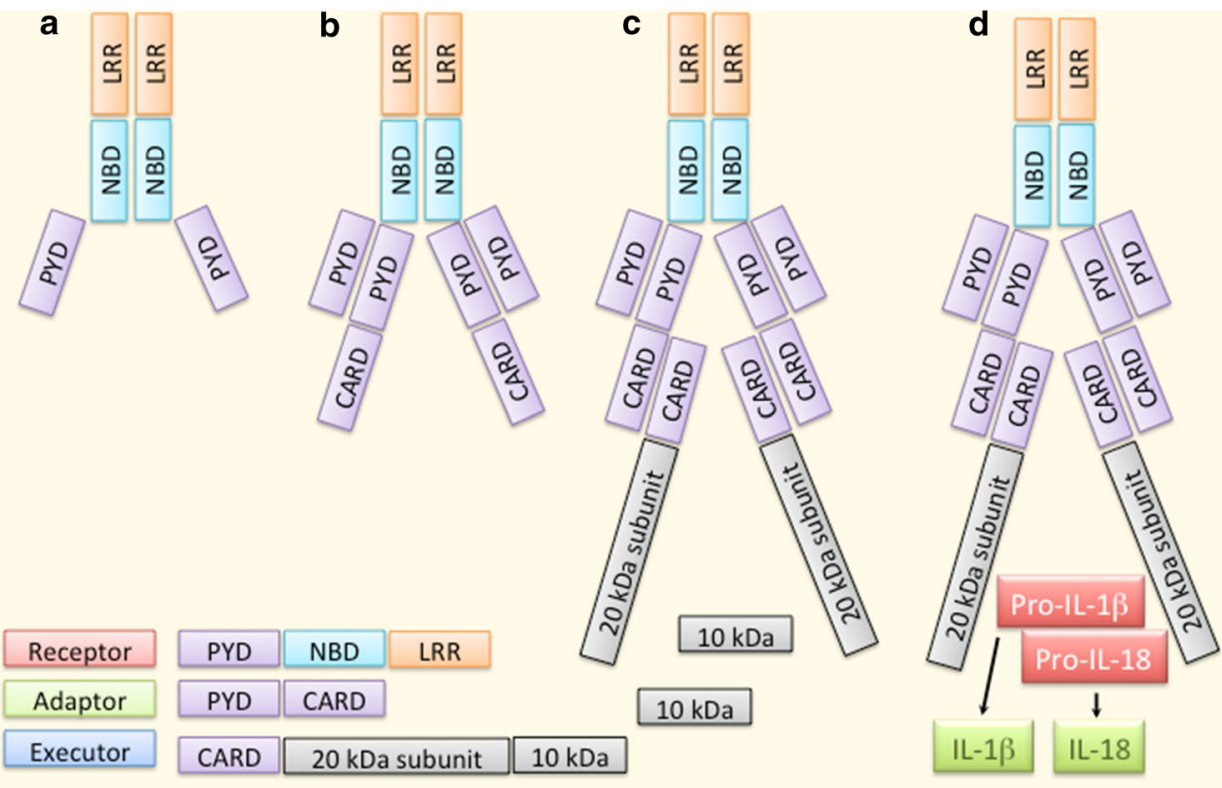

\section{Other inflammasome-related PRRs}

When it was observed that all cytosolic DNA does not become sensed by NLRP3, additional DNA sensors were sought. In 2009, four research groups arrived at the same conclusion, i.e. they all found that AIM2 (absent in melanoma 2) acted as an intracellular dsDNA sensor, whose activation also leads to the formation of the inflammasome [54-57]. In contrast to other DNA sensors, such as DAI (DNA-dependent activator of IFN-regulatory factors) and one other PYHIN protein, IFI16 (interferon gamma-inducible protein 16), AIM2 does not mediate the type I IFN production $[58,59]$. IFI16 is also a DNA sensor capable of assembling inflammasomes but it seems to specialize in searching for nuclear intruders, whereas AIM2 detects foreign DNA in the cytoplasm [54, 56, 57, 60, 61]. IFI16 has two HIN domains and a PYD domain, whereas AIM2 possesses only one HIN domain [62] (Fig. 3). RIG-I-like receptors (RLRs) are intracellular sensors that recognize cytosolic RNA derived either from viral infection or repeated replication [63] (Fig. 3).

\section{Inflammasomes become activated in AMD}

Inflammasome activation in the RPE was reported for the first time in 2012 [64-66]. In all studies so far, NLRP3 has been the responsible receptor in RPE cells and it is 
activated by a variety of inducing agents including lipofuscin and drusen components e.g. N-retinylidene-Nretinylethanolamine (A2E) and amyloid- $\beta$ [67, 68]. Fibrillar $A \beta 1-40$ can contribute to inflammasome signaling, for example by inducing the complement activation and MAC formation [69]. The ultimate mechanism remains to be clarified but in primary human lung epithelial cells, MAC triggered NLRP3 inflammasomes by increasing the intracellular $\mathrm{Ca}^{2+}$ concentration with the subsequent loss of the mitochondrial transmembrane potential [70]. There are many other danger signals for NLRP3 inflammasomes in the RPE, e.g. accumulation of Alu RNA, the appearance of the lipid peroxidation end product HNE (4-hydroxynonenal), as well as the presence of intracellular protein aggregates accompanied by a decline in the efficiency of autophagy [9, 64, 66]. UV radiation cannot reach the adult retina but blue light (peaking at approx. $450 \mathrm{~nm}$ ) is a potential inflammasome activator also at the retinal level [71]. A recent study revealed an interesting mechanistic link between excessive iron and AMD, showing that iron accumulation resulted in increased levels of short interspersed nuclear elements (SINEs), such as the NLRP3 agonist Alu RNA [64, 72]. Iron overload has been associated with the AMD-related tissue damage although the previously recognized mechanism has been linked to the induction of oxidative stress via the Fenton reaction that produces highly reactive hydroxyl radicals [73]. Furthermore, the iron-catalysed free radical-mediated production of 7-ketocholesterol $(7 \mathrm{KCh})$ from cholesterol has been shown to be capable of activating NLRP3 inflammasomes in the RPE [74]. Although details remain still largely sketchy, all three main mechanisms involving P2X7-dependent signaling, lysosomal destabilization, and oxidative stress have been shown to participate in the activation of NLRP3 also in the RPE-related inflammasome assembly [64-67, 75-77].

In addition to RPE, the inflammasome activation in the immune cells accumulating in the retinal area can contribute to the pathogenesis of AMD [65, 74, 78, 79]. For example, peripheral myeloid leukocytes responded by activation of the NLRP3 inflammasome after exposure to the $\mathrm{C} 1 \mathrm{q}$ complement component and other drusen fragments extracted from the AMD eyes [65]. Mouse mononuclear cells deficient of $c x 3 c r 1$ gene autoactivated the inflammasome signaling in an ATP/P2X7-dependent manner and thereby promoted photoreceptor toxicity [78]. The oxysterol $7 \mathrm{KCh}$ accumulating in the choriocapillaris, Bruch's membrane, and RPE layer induced even greater inflammasome-mediated cytokine production in microglia and macrophages than in RPE cells [74]. The exposure of microglia to sublethal concentrations of $7 \mathrm{KCh}$ can also lead to NLRP3 inflammasome-mediated activation and polarization of microglia towards the M1 phenotype [79].
When those cells were transplanted into the subretinal area, they were capable of promoting $\mathrm{CNV}$ (choroidal neovascularisation).

Although RPE and retinal inflammatory cells can produce both inflammasome-dependent cytokines, the cytokine release can be biased towards either IL- $1 \beta$ or IL18. In human ARPE-19 cells, HNE stimulated the production of both cytokines, whereas treatment of the cells with the proteasome inhibitor MG-132 and the vacuolar $\mathrm{H}+$ ATPase inhibitor, bafilomycin A favoured the release of IL-1 $\beta[9,66]$. Microglia and macrophages showed preferential production of IL-1 $\beta$ rather than IL-18 after an exposure to $7 \mathrm{KCh}$, whereas in RPE cells the situation was reversed [74]. When one considers the propensity of 7KChtreated microglia to promote $\mathrm{CNV}$ in the subretinal space, it could be argued that IL-1 $\beta$ may be involved in the pathological neovascularization process. This is in line with the evidence that IL-1 $\beta$ promoted the production of VEGF, whereas the release of IL-18 was inversely correlated with the amount of secreted VEGF [65, 80-83]. IL-18 has been proposed to be protective in wet AMD [65, 75, 82] but detrimental for geographic atrophy [64, 84, 85], but the overall situation needs to be fully clarified [86-89]. In therapeutic terms, one would wish to achieve a substantial inhibition of inflammasome activation. Some attempts have been made to arrest the inflammasome signaling in the RPE, e.g. by blocking the priming phase with vinpocetine, a compound that inhibits the activity of NF- $\mathrm{BB}$, or by preventing pro-caspase- 1 processing by administering a virally transduced CARD domain of the adaptor protein ASC $[90,91]$.

\section{Soluble PRRs}

In addition to many cell-associated receptors, there are also soluble pattern recognition molecules, such as circulating complement components and pentraxins. Activation of complement triggers a cascade of protease reactions producing opsonins, membrane pore complexes, and proinflammatory mediators [92]. There are three different ways to induce complement activation but all of them result in the formation of a complex called $\mathrm{C} 3$ convertase that cleaves component $\mathrm{C} 3$ into $\mathrm{C} 3 \mathrm{a}$ and $\mathrm{C} 3 \mathrm{~b}$ [93]. C3b binds to $\mathrm{C} 3$ convertase forming $\mathrm{C} 5$ convertase, which in turn cleaves the complement component $\mathrm{C} 5$ into $\mathrm{C} 5 \mathrm{a}$ and C5b [92]. Components C5a and C3a are called anaphylatoxins due to their ability to promote inflammation [92]. They can attract and activate mast cells, and act directly on blood vessels to increase their permeability and induce the production of adhesion molecules [94, 95]. C5a also recruits neutrophils and monocytes to the site of inflammation and activates these cells once they are in position 
[93]. C3a tends to attenuate rather than inducing the LPSinduced endotoxemia activating primarily other granulocytes than neutrophils $[96,97]$. In conjunction with MAC, $\mathrm{C} 3 \mathrm{a}$ and $\mathrm{C} 5 \mathrm{a}$ can also contribute to inflammasome signaling [98-102].

Pentraxins are evolutionarily conserved pattern recognition molecules that are often divided into two groups according to their length. Short pentraxins CRP (C-reactive protein) and SAP (serum amyloid $\mathrm{P}$ ) are the primary acute phase proteins in humans and mice, respectively [103, 104]. Production of CRP and SAP in the liver results from the systemic consequences of the actions of several potent pro-inflammatory cytokines, such as IL-6 and IL-1. PTX-3 is an example of a long pentraxin, produced locally by different types of cells, e.g. endothelial cells, fibroblasts, adipocytes, chondrocytes, and mononuclear phagocytes, in response to various pro-inflammatory signals, such as IL$1 \beta$, TNF- $\alpha$, and LPS [103, 104].

\section{Inheritable predisposition to AMD is strongly associated with alterations in the genes encoding complement factors}

\section{Complement factor $\mathrm{H}$ polymorphism is a major genetic risk factor for AMD}

Evidence emerging from recent studies has indicated that about half of the variation in the severity of AMD is explained by genetic factors [105]. Interestingly, a significant proportion of the AMD heritability is associated with the genes of the immune system, especially those coding for complement components [105]. The Y402H (Tyr402His) variant of the complement factor $\mathrm{H}$ is the best-known genetic risk factor for AMD [106-109]. This mutation is related to AMD susceptibility especially in Caucasians, whereas another missense mutation of CFH, I62V (Ile62$\mathrm{Val}$ ), is more prominent in Asian populations [110]. $\mathrm{CFH}$ is a glycoprotein composed of 20 short consensus repeats (SCR), whose main function is to inhibit the activation of the alternative complement pathway [111].

The acute phase protein C-reactive protein (CRP) is one of the many binding partners of CFH. Previously, SCR-7 and SCR-8/11 have been proposed as being domains capable of interacting with CRP but Okemefuna et al. challenged those results when they evaluated the properties of denatured CRP protein which had been used in earlier studies [111]. When these workers used functionally active proteins, they were able to confirm that SCR-6/8 could bind to CRP, and they identified SCR-16/20 as a new domain responsible for the CRP binding. Since the $\mathrm{Y} 402 \mathrm{H}$ substitution is located in the SCR-6/8 domain, its presence results in weaker binding properties of CFH to CRP [111,
112]. Therefore, RPE-choroid cells of homozygous $\mathrm{Y} 402 \mathrm{H}$ AMD patients are less well protected from the increased levels of CRP. The Y402H polymorphism does not, however, affect the binding of $\mathrm{CFH}$ to PTX3, whose primary and secondary binding sites are SCR19 and SCR7, respectively [113]. Malondialdehyde (MDA) is another binding partner of both SCR7 and SCR20 segments in CFH. MDA is common lipid peroxidation product that forms protein adducts capable of inducing inflammation and RPE damage [114, 115]. There are at least three strands of evidence for an association between oxidative stress and complement activation in the pathogenesis of AMD (1) phagocytosized oxidized POS material can disturb the synthesis and the secretion of CFH in RPE cells, (2) the inability of the H402Y variant to generate antiinflammatory $\mathrm{iC} 3 \mathrm{~b}$ components on MDA-loaded surfaces, (3) the finding that oxidative stress can regulate the expression of CFH and CFB [116-119]. Rohrer et al. also showed that oxidative stress predisposed RPE cells to complement-mediated injury and they later confirmed that alternative pathway of complement was needed to observe the ER stress and lipid accumulation by cigarette smoke and oxidative stress [120, 121]. By binding MDA, CFH could prevent the uptake of MDA-modified proteins by macrophages and block the induction of inflammation, but the H402Y polymorphism disturbed that binding process [115]. A chimeric mouse model was developed by expressing mutated SCR-6/8 of human $\mathrm{CFH}$ in the middle of murine CFH SCRs. It was found that RPE cells in these animals displayed an increased susceptibility to oxidative stress, elevated accumulation of MDA-protein adducts in the retina, higher amounts of activated microglia cells/macrophages in the subretinal space, and upregulated proinflammatory genes in the RPE, microglia, and macrophages [122]. Activated macrophages have also been found to be capable of regulating the expression of complement factors in RPE cells, and especially M1-type macrophages may promote the activation of the alternative pathway under inflammatory conditions [123].

\section{AMD-related variations in other complement factor genes}

AMD-related genetic variations have also been detected in the complement factors 3 (C3), and I (CFI) [124-130]. Moreover, alterations in the gene of serpin peptidase inhibitor, clade $\mathrm{G}$, member 1 (SERPING1), that regulates the activation of the complement system, have been associated with an increased risk of AMD [131]. Aging, proinflammatory cytokines TNF- $\alpha$ and IFN- $\gamma$, as well as extended exposure to POS material increase the expression of CFB in the RPE, which can promote AMD-associated neovascularization $[118,132,133]$. In combination with 
the accumulation of the $\mathrm{C} 3$ component, it has been reported that increased production of CFB by RPE cells also contributes to increased complement activation in the retina [118]. The findings that some point mutations in the $\mathrm{C} 2$ and CFB genes have been found protective against AMD support the hypothesis that there is an association between complement system and AMD [134-137].

The importance of complement activation has been emphasized especially in the development of wet AMD. The C3a, C5a, and MAC complexes found in subretinal drusen plaques have been linked to increased expression of VEGF and the formation of CNV [120, 138]. In addition, the production of CFB is itself sufficient to promote neovascularization, at least in the widely used animal model of wet AMD, where laser photocoagulation of RPE and Bruch's membrane induces CNV [133]. It has also been reported that this treatment not only induces the production of VEGF and attracts leukocytes to the injured tissue but also activates the complement cascade [138]. Consistent with the observations of activation, the complement regulatory protein, CD59, a protein that prevents the MAC formation, is capable of inhibiting the CNV process [139, 140]. In addition to highlighting the role of the drusen, it has been postulated that oxidative stress-induced phospholipid-containing neoepitopes become recognized by autoantibodies, and the formation of these pathological complexes can trigger the complement activation, resulting in VEGF secretion and CNV [141].

Complement factors can promote AMD also by activating inflammosome signaling [65]. In addition to enhancing inflammation, the C3a produced by RPE cells can induce the formation of basal deposits [142]. Amyloid$\beta$ which can be found in the drusen is capable of harnessing recruited macrophages and microglia to produce cytokines that induce CFB formation in the RPE [143]. The promotion of pro-inflammatory environment is also involved in the pathological effects of cigarette smoke when it induces C3a and C3b, especially in the absence of Nrf2 [144]. By regulating the production of IL-1 $\beta$ and IL-6, C3a and C5a can also promote Th17 differentiation and IL-17 production, which have recently emerged as potential players in adaptive immunity in the pathology of both wet and dry AMD [98, 145-149].

\section{AMD-related genetic variation in the immune system is not entirely restricted to complement factor genes}

There are other central immune system components associated with the genetic susceptibility to AMD e.g. the chemokine (fractalkine) receptor CX3CR1 and chemokine CCL-2 (C-C motif ligand 2; monocyte chemotactic protein
1, MCP-1). CX3CR1 is a double-edged sword-it can confer protection or cause destruction, depending on the tissue and pathophysiologic conditions [150]. There is convincing evidence suggesting that the normal function of CX3CR1 would be to protect from AMD rather than to cause the disease [151-155]. The protective role of CX3CR1 might result from its supportive functions, such as the regulation of retinal microglia and its tendency to diminish the expression of CCL2 and thereby the recruitment of pro-inflammatory $\mathrm{CCR} 2^{+}$monocytes to the retina $[155,156] . C x 3 c r 1^{G F P / G F P}$ murine monocytes were shown to contribute to photoreceptor degeneration by stimulating the autonomous activation of P2X7 receptors and IL-1 $\beta$ secretion through spontaneous ATP release [78]. These findings suggest that CX3CR1 would play a significant role in maintaining tissue homeostasis, a process which has been termed as parainflammation [157, 158]. Genetic variants V249I (Val241Ile) and T280M (Thr280Met) of CX3CR alter the binding of fractalkine by circulating leukocytes and along with other age-related diseases, this defect has been associated with the development of AMD [151, 159-162]. There are also contradictory results, i.e. no evidence for altered function of CX3CR1 in the pathogenesis of AMD [163-165]. A number of association studies have been performed using double knock-out mice lacking both $C x 3 c r l$ and $C c l 2$ genes [152-155, 163] but their findings have been questioned since many transgenic mice carry the $r d 8$ (retinal degeneration 8 ) mutation in their $C r b-1$ (crumbs-like 1) gene that also results in retinal degeneration [164, 166, 167]. Subsequent studies have found contradictory results when using mice that do not carry the $C r b-1 / r d 8$ mutation, although they have provided further evidence that mice with the $r d 8$ background still develop an RPE-related pathology reminiscent of AMD [154, 163, 164, 168, 169]. However, in a recent pooled analysis from five prospective human studies, no unambiguous association could be detected between common CX3CR1 variants and AMD [165]. Instead, the effect of CX3CR1 variants was found to depend on several factors, such as diet, obesity, and the presence of predisposing variants of the complement components [165]. This conclusion is not surprising in view of the well-known multifactorial nature of AMD pathogenesis.

In addition to the double-knockout mouse model, there are also mice lacking only the $C c l 2$ gene. Several studies performed using those animals, have indicated that the absence of CCL2 evokes changes typical of AMD, and this could also be an indication of a failed parainflammatory response [170, 171]. However, a study conducted with AMD patients and control subjects from The Netherlands and the US, detected no associations between CCL2, CCR2, or TLR4 and AMD [172]. 


\section{Inflammatory response}

Activation of their PRRs causes cells to secrete cytokines and chemokines, e.g. IL-1 $\beta$, IL-6, TNF- $\alpha$, IL-12, and IL-8 [CXCL8; chemokine (C-X-C motif) ligand 8], to which other cells respond (Fig. 5). The local effects of IL-1 $\beta$ and TNF- $\alpha$ include the activation of endothelial cells, which is one of the most prominent processes at the beginning of inflammation [173]. Endothelial cell activation is characterized by increased expression of leukocyte adhesion molecules, cytokines, growth factors, and HLA molecules [174, 175]. Moreover, in order to prevent the spreading of a potential pathogen, their phenotype changes from antithrombotic to prothrombotic [174]. Subsequently, the permeability of blood vessels increases and circulating leukocytes begin to make contact with the adhesion molecules expressed by endothelial cells [175] (Fig. 5). Leukocytes reach their target location at the site of inflammation by following the increasing chemokine gradient, finally leaving the circulation and moving towards the damaged tissue [176] (Fig. 5). It is not only white blood cells that enter the inflamed tissue but also fluids and various plasma proteins gain access to these sites of tissue damage [175]. Together they induce the typical signs of inflammation, i.e. rubor (redness), tumor (swelling), calor (heat), and dolor (pain) [177]. Later, functio laesa (impaired function) and fluor (secretion) have also been suggested as being other characteristics of inflammation [177, 178].

IL-8 or CXCL8 was the first chemokine to be characterized; this compound attracts neutrophilic granulocytes that are the first effector cells to reach the site of inflammation [173, 179, 180] (Fig. 5). Other CXC chemokines, such as KC (keratinocyte-derived chemokine; CXCL1) and MIP-2 (CXCL2) also participate in the recruitment of neutrophils [180]. Neutrophils are efficient phagocytes and important in destroying microbes if they are the cause of the acute inflammation. Activated neutrophils kill pathogens in several ways (1) by producing reactive oxygen species, (2) by releasing active peptides, and (3) by forming extracellular fibers called neutrophil extracellular traps (NETs) through the release of granule proteins and chromatin $[181,182]$. NETs not only bind microbes, preventing them from spreading and ensuring that there are high local concentrations of antimicrobial agents but these fibers can also promote adaptive immunity and function even in sterile inflammation [181, 183]. It is this active interaction with other immune cells that broadens the significance of neutrophils in innate and adaptive immunity [184]. Neutrophils also regulate angiogenesis by producing VEGF $[180,185]$.

Monocytes follow neutrophils to inflammatory foci and once embedded in the tissues, they differentiate to macrophages or dendritic cells depending on local conditions

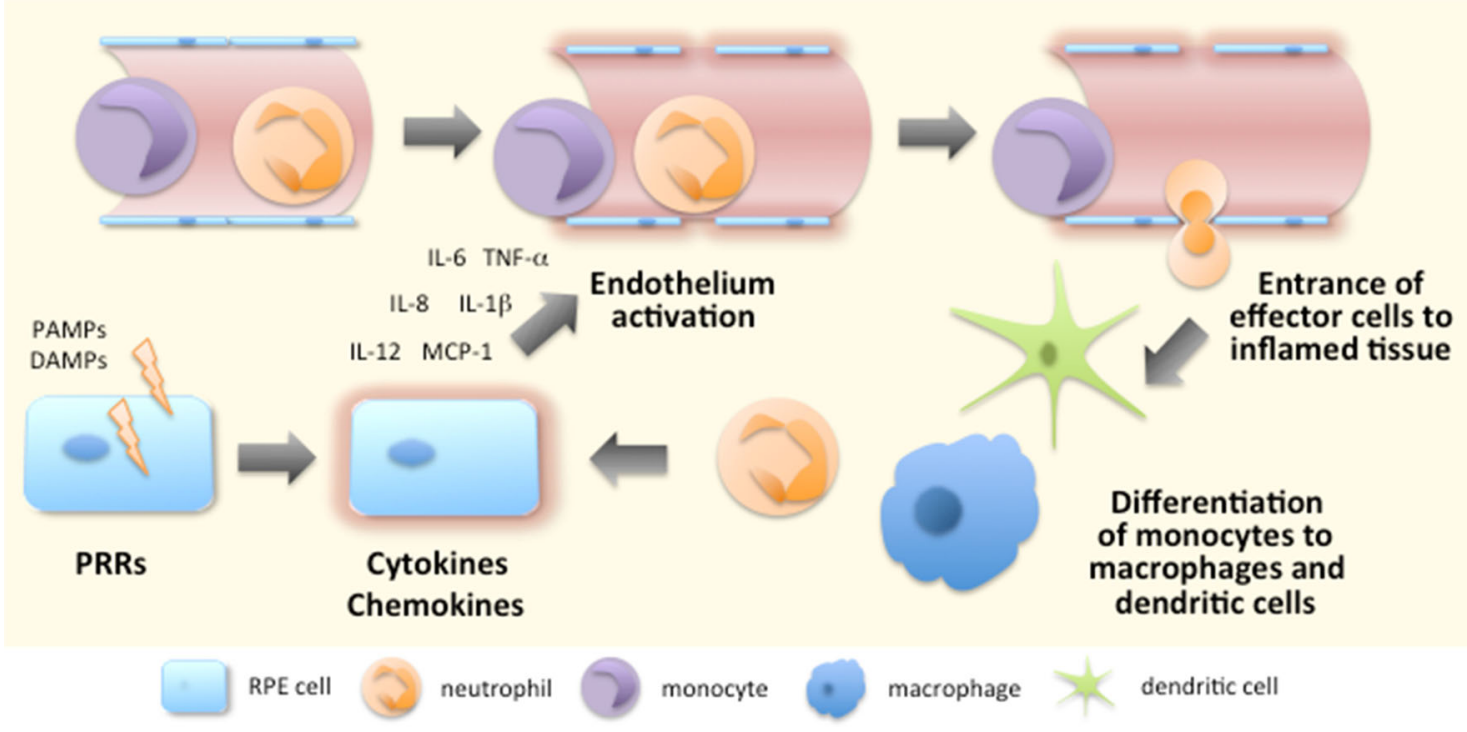

Fig. 5 Initiation of the inflammatory response. Recognition of PAMPs and DAMPs by PRRs triggers intracellular signaling resulting in the production of pro-inflammatory cytokines and chemokines. The released mediators contribute to the activation of endothelium, e.g. elevated expression of adhesion molecules and increased vascular permeabilization. Circulating leukocytes interact with adhesion molecules expressed by endothelium, slow down their speed and start rolling along the endothelial layer. The chemokine gradient which originates from the inflamed tissue becomes sensed by leukocytes that start expressing integrins to permit their tighter binding to endothelial cells. Finally, leukocytes leave the circulation to seek out the inflamed tissue where monocytes differentiate into macrophages and dendritic cells according to the local conditions 
with cytokines, growth factors, and possible microbial components [186, 187] (Fig. 5). Macrophages and dendritic cells are efficient antigen-presenting cells (APCs) that can internalize particulate antigens e.g. derived from pathogens or dying cells $[188,189]$. After binding the antigen, cells migrate from inflamed tissue to local lymph nodes where they present it to other cells of the immune system and TNF- $\alpha$ is involved in promoting the transition of these antigen-presenting cells [188, 189]. The cells of adaptive immunity assist innate immune cells in coping with the inflammation but also make the responses more specific in order to prevent collateral damage to healthy cells in the vicinity of the inflamed tissue [190].

Macrophages are very flexible cells changing their phenotype and functions depending on the environment in which they find themselves [191]. An inflammatory environment favors M1 macrophages that produce high levels of pro-inflammatory cytokines, such as (pro)IL-1 $\beta$, TNF- $\alpha$, IL-6, IL-12, as well as inducible nitric oxide synthase (iNOS) leading to the Th1-type immune response [192, 193]. The so-called classically activated M1 macrophages become activated by IFN- $\gamma$ and TNF- $\alpha$. IFN- $\gamma$ can be produced by natural killer (NK) cells during innate immune responses, and by $\mathrm{T}$ helper 1 (Th1) and cytotoxic $\mathrm{CD}^{+} \mathrm{T}$ lymphocytes during adaptive immune responses, whereas antigen-presenting cells (APCs), including macrophages themselves, are efficient in producing TNF- $\alpha[191,192]$.

Th2-type cytokines IL-4 and IL-13 are direct activators of the M2 macrophages [194]. Those cytokines can be secreted by many different cell types including innate and adaptive immune cells, epithelial cells, and tumor cells. In addition to playing important roles in physiological events, such as homeostasis, wound healing, and tissue repair, the actions of M2 macrophages have been implicated in pathological processes, such as inflammation, hypersensitivity, or choroidal neovascularization [191, 194, 195]. However, the inflammation associated with M2 macrophages is not as intense as that induced by their M1 counterparts. For example, M2 macrophages are inefficient in antigen presentation, and they have rather poor capabilities for eliminating intracellular pathogens, nor do they evoke the production of Th1-type proinflammatory cytokines or toxic oxygen and/or nitrogen radicals [196]. M2 macrophages are also poor at dealing with infections caused by intracellular pathogens [191]. Moreover, while the propensity of M2 macrophages to secrete extracellular matrix components certainly helps in wound healing, in chronic conditions, it also predisposes to pathological fibrosis [191, 194]. In addition to neutrophils, the chemokines released by M2 macrophages attract and activate also other granulocytes, i.e. basophils, eosinophils, and mast cells. These cells are known to participate in the typical Th2-type responses; i.e. the beneficial actions, e.g. combatting parasite infections but also in detrimental effects, such as evoking allergies and hypersensitivity reactions [194].

In addition to distributing the subdivision into M1 and M2 cells, there is a third functional class of macrophagesso-called regulatory macrophages, which have been classified as a subgroup of M2 macrophages [196]. Similar to the M1 cells, regulatory macrophages can produce high levels of nitric oxide (NO), express the co-stimulatory molecule CD86, and present antigens to $\mathrm{T}$ lymphocytes [196]. However, regulatory macrophages promote the Th2type response by producing high amounts of IL-10, whereas M1 cells favor Th1-type reactions by releasing IL12 [196]. IL-10 is an anti-inflammatory cytokine and therefore, regulatory macrophages are thought to attenuate inflammation [191]. A great many different signals, such as immune complexes of antibodies and soluble antigens, prostaglandins, glucocorticoids, apoptotic cells, and IL-10, can contribute to the activation of regulatory macrophages [191]. In addition to priming, a subsequent signal, e.g. mediated through a TLR is needed for their full activation [191].

\section{Aging induces changes in the immune system}

Immunosenescence is a term used to describe altered immune functions during aging. Despite the apparent slowdown of many functions, the term dysfunction with respect to immunosenescence is somewhat misleading. Instead of a total loss of the function, aging alters the functions of the immune system so that it no longer resembles the immune system of the young individuals. Simultaneously with a reduction in the naïve $\mathrm{T}$ cell pool, there is an increase in the numbers of memory $\mathrm{T}$ cells, especially those of CD8 $+\mathrm{T}$ cells that have lost their CD80 and CD86-binding co-stimulatory molecule CD28 [197, 198]. The increased memory $\mathrm{T}$ cell numbers have been postulated to result from an attempt to maintain the cell count in balance, but this may lead to the exhaustion of remaining $\mathrm{T}$ lymphocytes with limited replicative capacity [199]. The loss of CD28 expression is accompanied by an age-dependent de novo induction of prototypic NK cell receptor CD56 on non-dividing senescent T cells [200].

In addition to quantitative and qualitative changes appearing in $\mathrm{T}$ cells, age-related modifications in the $\mathrm{B}$ cell pool contribute to unsuccessful vaccination responses, as well as to the increased frequency and greater severity of infections [198]. Other unfavorable changes include decreased amounts of mature human B cells, diminished reactivity to $\mathrm{T}$ cell-dependent antigens, and a deficiency in class switch recombination. 
The functions of the major innate immune effector cells, such as neutrophils, monocytes, macrophages, and dendritic cells also undergo age-related modifications. Those include changes in the PRR expression, aberrant signaling and disturbed cytokine production, as well as decreased migration, phagocytosis, and killing of ingested micro-organisms [201]. For example, the diminished capacity of neutrophils to phagocytize pathological particles and the failure to induce a respiratory burst to destroy ingested material accompanied by an inability to undergo apoptosis can contribute to prolonged inflammation. Furthermore, it is known that the clearance of apoptotic cells by macrophages is diminished [202].

\section{Inflammation is clearly present in the AMD pathology}

Increased oxidative stress, reduced proteostasis, and everincreasing dysfunctionality are just some of the stress factors that can induce inflammation in aged RPE cells. The concurrent attenuation of protective mechanisms, e.g. antioxidant responses and DNA repair systems, further amplify the destructive effects and promote the conversion of what should be a protective response into a chronic and deleterious pathological process.

\section{Drusen serve as inflammatory nodes in the pathogenesis of AMD}

RPE cells are the origin of numerous components found in drusen deposits; in conjunction with pigment mottling, these are the first clinical signs detectable in the AMD [25, 203-205]. Subretinal drusen resemble the extracellular deposits found in Alzheimer's disease, amyloidosis, atherosclerosis, elastosis, and dense deposit disease [38, 206, 207]. Drusen are known to contain many potentially damaging constituents including lipids, lipoproteins, RPEderived cellular debris, e.g. organelles, melanin granules, and lipofuscin, amyloid- $\beta$, apolipoprotein E (APOE), clusterin, serum albumin, crystallin, tissue metalloproteinase inhibitor 3 (TIMP-3), and oxidation by-products, as well as numerous inflammation-related factors, such as complement components, immunoglobulins, HLA molecules, and acute phase proteins like vitronectin, fibrinogen, $\alpha 1$-antichymotrypsin, and pentraxins [208-218]. Elevated oxidative processes, stressed autophagy, and increased exoand transcytosis in RPE cells have been associated with the formation of drusen between the RPE and the choroid layers $[219,220]$. Moreover, there is solid evidence suggesting that chronic low-level inflammation and complement activation play major roles in the formation of drusen [212, 217, 221-226]. Isolated drusen material has also been proven to be pro-inflammatory through the activation of both traditional and the more recently discovered signaling systems, such as NF- $\kappa \mathrm{B}$ and the inflammasome pathways, respectively [65, 68, 90, 227].

\section{Leukocytes contribute to the pathogenesis of AMD}

Retinal microglia and recruited macrophages play an important role in parainflammation, i.e. the maintenance of tissue homeostasis and the clearance of debris from the subretinal space [158, 228, 229]. Aging induces changes in the immune system, which also alters the function of leukocytes. For example, the increased activity of matrix metalloproteases (MMPs) enhances the cleavage of FasL on the cell surfaces resulting in a limited apoptosis of invading inflammatory cells [195, 230-233]. Soluble FasL also recruits M2-type macrophages that promote neovascularization [195, 234]. In a healthy eye, M2 macrophages in particular confer protection from degenerative changes but in AMD, also the proportion of pro-inflammatory M1 macrophages increases and the stress becomes overwhelming [235, 236]. After disrupting the homeostasis of the eye, the accumulation of immune cells causes more harm than benefit. The altered conditions may also change the effects of cytokines depending on the stimulant. For example, $\mathrm{Wu}$ et al. have demonstrated how the anti-inflammatory cytokine, IL-10, can inhibit M1 but not M2 macrophage-derived VEGF production in a context-dependent manner [237].

Although normally associated with healthy aging, an inflammatory environment also alters the functionality of senescent $\mathrm{T}$ cells. Increased numbers of $\mathrm{CD} 56^{+} \mathrm{T}$ cells have been detected in the blood of AMD patients when compared to aged control subjects [238]. Elevated numbers of $\mathrm{CD}^{+} 6^{+}$lymphocytes have been associated with many autoimmune diseases, such as rheumatoid arthritis, Behçet's uveitis, psoriasis, and systemic lupus erythematosus [239-242]. Regardless of the numerous autoimmunity-related markers, such as anti-retinal and anti-RPE autoantibodies and diverse contributions of IL-17, AMD cannot simply be designated as an autoimmune disease $[145,146,243-248]$. Changes in the $\mathrm{CD}^{+} 6^{+} \mathrm{T}$ cell levels do not only occur in autoimmune disorders but have also been detected, e.g. in the coronary artery disease, a condition that shares various risk factors and biomarkers with AMD and may even predispose to the disease [249, 250].

\section{Systemic inflammatory biomarkers of AMD}

The multitude of inflammation-related plasma proteins in the drusen refers to the involvement of systemic immunological processes in the pathogenesis of AMD. Some research has been conducted with urine samples 
[251] but most putative biomarkers have been investigated in peripheral blood, serum, or plasma. For example, increased levels of complement components have been assayed in the blood of AMD patients [252-255]. Elevated levels of regulatory proteins, such as CD21 (complement receptor 2), CD35 (complement receptor 1), CD46 (membrane cofactor protein, MCP), CD55 (decay-accelerating factor, DAF), or CD59 (protectin), may resemble increased complement activity but a significantly lower expression can be evidence of dysregulated control [256, 257]. Instead, the lack of association between AMD and SNPs in CFP (properdin), CD46, CD55, and CD59 suggests that the gene variants of those regulatory proteins do not increase an individual's susceptibility to AMD [258]. In contrast, AMD patients with the homozygous $\mathrm{CC}$ variant of the $\mathrm{Y} 402 \mathrm{H}$ substitution in $\mathrm{CFH}$ displayed higher systemic concentrations of central pro-inflammatory cytokines IL-6 and TNF- $\alpha$ when compared to heterozygous CT or non-risk TT variants [259]. Both of these cytokines can promote pathological changes in the RPE [260-262]. TNF- $\alpha$ also reflects the activity of $\mathrm{T}$ lymphocytes and macrophages that are known to be associated with the pathological changes of AMD [263-267]. In particular, macrophage-derived TNF- $\alpha$ and IL-1 $\beta$ might serve as biomarkers for choroidal neovascularization [263, 264]. In addition, macrophage activation may also result in the release of MMPs, and increased plasma levels of these enzymes have been detected in AMD patients [268]. The association between elevated systemic IL-6 levels and AMD has been supported by several other studies [269-271] although contrasting results have also been published [272].

The acute phase protein, CRP, has been one of the most widely studied putative blood biomarkes for AMD. Despite the somewhat inconsistent findings, one meta-analysis conducted by Hong et al. in 2011 from 11 studies (nine cross-sectional and two prospective) with almost 42,000 participants revealed that those subjects with serum levels of CRP higher than $3 \mathrm{mg} / \mathrm{l}$ had a twofold higher likelihood of late AMD in comparison to those subjects having CRP levels lower than $1 \mathrm{mg} / \mathrm{l}$ [273]. The pooled analysis of five large prospective nested case-control studies reported by Mitta et al. in 2013 supported the view that elevated serum CRP levels could be associated with AMD [274]. In a recent study with over 5000 aged British subjects, higher serum CRP levels were associated with increased risk of AMD in the longitudinal, but not in the cross-sectional analysis [275]. There was a modest association between high CRP levels and the 20-year cumulative risk for early AMD in the Beaver Dam Eye Study with almost 6000 participants [271].

Significant and moderate increases in the plasma concentrations of inflammasome-related cytokines IL-18 and IL-1 $\beta$, respectively, in patients carrying the high risk CC alleles of $\mathrm{Y} 402 \mathrm{H}$ variant raises an intriguing possibility that there is systemic or continuous inflammasome activation in patients suffering from dry AMD [259]. In addition to those factors mentioned above, there are many other inflammation-related factors, such as eotaxin, fibrinogen, IP-10, long pentraxin 3, sFasL (soluble Fas ligand), sICAM-1 (soluble intercellular adhesion molecule1), sTNFRII (TNF-a receptor II), that have also been proposed as biomarkers of AMD [267, 272, 276-280]. Although there has been increased research in obtaining reliable biomarkers for AMD, no selective blood biomarker has been found that meets the requirements of early AMD detection. The pro-inflammatory environment may, however, nudge cellular immunity towards a pathological phenotype with these changes becoming visible as the subject reaches an advanced age.

\section{Summary}

Inflammation is a cellular defence mechanism, in which foreign or damaged material becomes sensed by various PRRs [28]. The ligand recognition process triggers the activation of intracellular signaling pathways resulting in the production of numerous pro-inflammatory mediators [34]. The activated endothelium in the blood vessels promotes and attracts effector cells and there is an accumulation of soluble proteins within inflamed tissue [174, 175]. Effector leukocytes, such as granulocytes, monocyte-derived macrophages and dendritic cells, as well as lymphocytes utilize a multitude of mechanisms for meeting the challenge of restoring the tissue homeostasis [181, 183, 184, 188-194, 196].

AMD is an ocular disease with inflammation strongly interwoven into its pathogenesis. Several PRRs become activated by endogenous intra- and extracellular danger signals inducing an inflammatory response beyond the homeostasis-maintaining para-inflammation. Degenerative changes in RPE cells trigger a vicious circle that promotes the development of chronic inflammation in the retina and the choroid. Age-related changes in the immune system contribute to this destructive process by altering the functions of immune cells. Currently, there is no cure to AMD, and changes at the cellular level are already significant when the first symptoms appear. Various local and systemic inflammatory molecules have been proposed as being biomarkers of AMD but at present, no specific and reliable marker has been found. If there were a selective marker, this would help in the initial clinical diagnosis, preferably before the disease had progressed to a symptomatic phase. Moreover, biomarkers could also help to clarify the mechanisms behind AMD as well as helping to monitor the response to therapy. 
Acknowledgments Dr. Ewen MacDonald is warmly acknowledged for the language revision. This work was financially supported by the Finnish Cultural Foundation, the Alfred Kordelin Foundation, the Finnish Eye Foundation, and the Kuopio University Hospital.

\section{Compliance with ethical standards}

Conflict of interest The authors declare that they have no competing interests.

Open Access This article is distributed under the terms of the Creative Commons Attribution 4.0 International License (http:// creativecommons.org/licenses/by/4.0/), which permits unrestricted use, distribution, and reproduction in any medium, provided you give appropriate credit to the original author(s) and the source, provide a link to the Creative Commons license, and indicate if changes were made.

\section{References}

1. Thomas CJ, Schroder K (2013) Pattern recognition receptor function in neutrophils. Trends Immunol 34:317-328. doi:10. 1016/j.it.2013.02.008

2. Lambrecht BN, Hammad H (2012) The airway epithelium in asthma. Nat Med 18:684-692. doi:10.1038/nm.2737

3. Franceschi C, Bonafe M, Valensin S, Olivieri F, De Luca M, Ottaviani E, De Benedictis G (2000) Inflamm-aging. An evolutionary perspective on immunosenescence. Ann N Y Acad Sci 908:244-254. doi:10.1111/j.1749-6632.2000.tb06651.x

4. Salvioli S, Capri M, Valensin S, Tieri P, Monti D, Ottaviani E, Franceschi C (2006) Inflamm-aging, cytokines and aging: state of the art, new hypotheses on the role of mitochondria and new perspectives from systems biology. Curr Pharm Des 12:3161-3171. doi:10.2174/138161206777947470

5. Jarrett SG, Boulton ME (2012) Consequences of oxidative stress in age-related macular degeneration. Mol Aspects Med 33:399-417. doi:10.1016/j.mam.2012.03.009

6. Ambati J, Atkinson JP, Gelfand BD (2013) Immunology of agerelated macular degeneration. Nat Rev Immunol 13:438-451. doi:10.1038/nri3459

7. Viiri J, Amadio M, Marchesi N, Hyttinen JM, Kivinen N, Sironen R, Rilla K, Akhtar S, Provenzani A, D'Agostino VG, Govoni S, Pascale A, Agostini H, Petrovski G, Salminen A, Kaarniranta K (2013) Autophagy activation clears ELAVL1/ HuR-mediated accumulation of SQSTM1/p62 during proteasomal inhibition in human retinal pigment epithelial cells. PLoS One 8:e69563. doi:10.1371/journal.pone.0069563

8. Mitter SK, Song C, Qi X, Mao H, Rao H, Akin D, Lewin A, Grant M, Dunn W Jr, Ding J, Bowes Rickman C, Boulton M (2014) Dysregulated autophagy in the RPE is associated with increased susceptibility to oxidative stress and AMD. Autophagy 10:1989-2005. doi:10.4161/auto.36184

9. Piippo N, Korkmaz A, Hytti M, Kinnunen K, Salminen A, Atalay M, Kaarniranta K, Kauppinen A (2014) Decline in cellular clearance systems induces inflammasome signaling in human ARPE-19 cells. Biochim Biophys Acta 1843:3038-3046. doi:10.1016/j.bbamcr.2014.09.015

10. Ferrington DA, Sinha D, Kaarniranta K (2015) Defects in retinal pigment epithelial cell proteolysis and the pathology associated with age-related macular degeneration. Prog Retin Eye Res. doi:10.1016/j.preteyeres.2015.09.002

11. Nowak JZ (2006) Age-related macular degeneration (AMD): pathogenesis and therapy. Pharmacol Rep 58:353-363
12. Stefanini FR, Badaro E, Falabella P, Koss M, Farah ME, Maia M (2014) Anti-VEGF for the management of diabetic macular edema. J Immunol Res 2014:632307. doi:10.1155/2014/632307

13. Friedman DS, O'Colmain BJ, Munoz B, Tomany SC, McCarty C, de Jong PT, Nemesure B, Mitchell P, Kempen J, Eye Diseases Prevalence Research Group (2004) Prevalence of agerelated macular degeneration in the US. Arch Ophthalmol 122:564-572. doi:10.1001/archopht.122.4.564

14. Prokofyeva E, Zrenner E (2012) Epidemiology of major eye diseases leading to blindness in Europe: a literature review. Ophthalmic Res 47:171-188. doi:10.1159/000329603

15. Pascolini D, Mariotti SP (2012) Global estimates of visual impairment: 2010. Br J Ophthalmol 96:614-618. doi:10.1136/ bjophthalmol-2011-300539

16. De Falco S (2014) Antiangiogenesis therapy: an update after the first decade. Korean J Intern Med 29:1-11. doi:10.3904/kjim. 2014.29.1.1

17. CATT Research Group, Martin DF, Maguire MG, Ying GS, Grunwald JE, Fine SL, Jaffe GJ (2011) Ranibizumab and bevacizumab for neovascular age-related macular degeneration. N Engl J Med 364:1897-1908. doi:10.1056/NEJMoa1102673

18. Kaarniranta K, Kauppinen A, Blasiak J, Salminen A (2012) Autophagy regulating kinases as potential therapeutic targets for age-related macular degeneration (AMD). Future Med Chem 4:2153-2161. doi:10.4155/fmc.12.169

19. Chew EY, Clemons TE, Agron E, Sperduto RD, Sangiovanni JP, Kurinij N, Davis MD, Age-Related Eye Disease Study Research Group (2013) Long-term effects of vitamins C and E, betacarotene, and zinc on age-related macular degeneration: AREDS Report No. 35. Ophthalmology 120(1604):1611.e4. doi:10.1016/ j.ophtha.2013.01.021

20. Schmidt-Erfurth U, Kaiser PK, Korobelnik JF, Brown DM, Chong V, Nguyen QD, Ho AC, Ogura Y, Simader C, Jaffe GJ, Slakter JS, Yancopoulos GD, Stahl N, Vitti R, Berliner AJ, Soo Y, Anderesi M, Sowade O, Zeitz O, Norenberg C, Sandbrink R, Heier JS (2014) Intravitreal aflibercept injection for neovascular age-related macular degeneration: 96-week results of the VIEW studies. Ophthalmology 121:193-201. doi:10.1016/j.ophtha. 2013.08.011

21. Damico FM, Gasparin F, Scolari MR, Pedral LS, Takahashi BS (2012) New approaches and potential treatments for dry agerelated macular degeneration. Arq Bras Oftalmol 75:71-76. doi:10.1590/S0004-27492012000100016

22. Sparrow JR, Hicks D, Hamel CP (2010) The retinal pigment epithelium in health and disease. Curr Mol Med 10:802-823. doi:10.2174/156652410793937813

23. Strauss $O(2005)$ The retinal pigment epithelium in visual function. Physiol Rev 85:845-881. doi:10.1152/physrev.00021. 2004

24. Williams RA, Brody BL, Thomas RG, Kaplan RM, Brown SI (1998) The psychosocial impact of macular degeneration. Arch Ophthalmol 116:514-520. doi:10.1001/archopht.116.4.514

25. Kaarniranta K, Sinha D, Blasiak J, Kauppinen A, Vereb Z, Salminen A, Boulton ME, Petrovski G (2013) Autophagy and heterophagy dysregulation leads to retinal pigment epithelium dysfunction and development of age-related macular degeneration. Autophagy 9:973-984. doi:10.4161/auto.24546

26. Winkler BS, Boulton ME, Gottsch JD, Sternberg P (1999) Oxidative damage and age-related macular degeneration. Mol Vis $5: 32$

27. Feeney-Burns L, Berman ER, Rothman H (1980) Lipofuscin of human retinal pigment epithelium. Am J Ophthalmol 90:783-791. doi:10.1016/S0002-9394(14)75193-1

28. Masters SL, De Nardo D (2014) Innate immunity. Curr Opin Immunol 26:v-vi. doi:10.1016/j.coi.2013.12.006 
29. Schmidt AM, Vianna M, Gerlach M, Brett J, Ryan J, Kao J, Esposito C, Hegarty H, Hurley W, Clauss M (1992) Isolation and characterization of two binding proteins for advanced glycosylation end products from bovine lung which are present on the endothelial cell surface. J Biol Chem 267:14987-14997

30. Neeper M, Schmidt AM, Brett J, Yan SD, Wang F, Pan YC, Elliston K, Stern D, Shaw A (1992) Cloning and expression of a cell surface receptor for advanced glycosylation end products of proteins. J Biol Chem 267:14998-15004

31. Lin L (2006) RAGE on the Toll road? Cell Mol Immunol 3:351-358

32. Gonzalez I, Romero J, Rodriguez BL, Perez-Castro R, Rojas A (2013) The immunobiology of the receptor of advanced glycation end-products: trends and challenges. Immunobiology 218:790-797. doi:10.1016/j.imbio.2012.09.005

33. Kawai T, Akira S (2010) The role of pattern-recognition receptors in innate immunity: update on Toll-like receptors. Nat Immunol 11:373-384. doi:10.1038/ni.1863

34. Kumar H, Kawai T, Akira S (2011) Pathogen recognition by the innate immune system. Int Rev Immunol 30:16-34. doi:10. 3109/08830185.2010.529976

35. Jin B, Sun T, Yu XH, Yang YX, Yeo AET (2012) The effects of TLR activation on T-cell development and differentiation. Clin Dev Immunol 2012:836485. doi:10.1155/2012/836485

36. Kawasaki T, Kawai T (2014) Toll-like receptor signaling pathways. Front Immunol 5:461. doi:10.3389/fimmu.2014.00461

37. Schroder K, Zhou R, Tschopp J (2010) The NLRP3 inflammasome: a sensor for metabolic danger? Science 327:296-300. doi:10.1126/science. 1184003

38. Kaarniranta K, Salminen A, Haapasalo A, Soininen H, Hiltunen M (2011) Age-related macular degeneration (AMD): Alzheimer's disease in the eye? J Alzheimers Dis 24:615-631. doi:10. 3233/JAD-2011-101908

39. Geijtenbeek TB, Gringhuis SI (2009) Signalling through C-type lectin receptors: shaping immune responses. Nat Rev Immunol 9:465-479. doi:10.1038/nri2569

40. Chen GY (2014) Role of Nlrp6 and Nlrp12 in the maintenance of intestinal homeostasis. Eur J Immunol 44:321-327. doi:10. 1002/eji.201344135

41. Ting JP, Lovering RC, Alnemri ES, Bertin J, Boss JM, Davis BK, Flavell RA, Girardin SE, Godzik A, Harton JA, Hoffman HM, Hugot JP, Inohara N, Mackenzie A, Maltais LJ, Nunez G, Ogura Y, Otten LA, Philpott D, Reed JC, Reith W, Schreiber S, Steimle V, Ward PA (2008) The NLR gene family: a standard nomenclature. Immunity 28:285-287. doi:10.1016/j.immuni. 2008.02.005

42. Hsu LC, Ali SR, McGillivray S, Tseng PH, Mariathasan S, Humke EW, Eckmann L, Powell JJ, Nizet V, Dixit VM, Karin M (2008) A NOD2-NALP1 complex mediates caspase-1-dependent IL-1beta secretion in response to Bacillus anthracis infection and muramyl dipeptide. Proc Natl Acad Sci USA 105:7803-7808. doi:10.1073/pnas.0802726105

43. Davis BK, Wen H, Ting JP (2011) The inflammasome NLRs in immunity, inflammation, and associated diseases. Annu Rev Immunol 29:707-735. doi:10.1146/annurev-immunol-031210101405

44. Katagiri N, Shobuike T, Chang B, Kukita A, Miyamoto H (2012) The human apoptosis inhibitor NAIP induces pyroptosis in macrophages infected with Legionella pneumophila. Microbes Infect 14:1123-1132. doi:10.1016/j.micinf.2012.03. 006

45. Khare S, Dorfleutner A, Bryan NB, Yun C, Radian AD, de Almeida L, Rojanasakul Y, Stehlik C (2012) An NLRP7-containing inflammasome mediates recognition of microbial lipopeptides in human macrophages. Immunity 36:464-476. doi:10.1016/j.immuni.2012.02.001
46. Vladimer GI, Weng D, Paquette SW, Vanaja SK, Rathinam VA, Aune MH, Conlon JE, Burbage JJ, Proulx MK, Liu Q, Reed G, Mecsas JC, Iwakura Y, Bertin J, Goguen JD, Fitzgerald KA, Lien E (2012) The NLRP12 inflammasome recognizes Yersinia pestis. Immunity 37:96-107. doi:10.1016/j. immuni.2012.07.006

47. Minkiewicz J, de Rivero Vaccari JP, Keane RW (2013) Human astrocytes express a novel NLRP2 inflammasome. Glia 61:1113-1121. doi:10.1002/glia.22499

48. Allen IC (2014) Non-inflammasome forming NLRs in inflammation and tumorigenesis. Front Immunol 5:169. doi:10.3389/ fimmu.2014.00169

49. Lupfer C, Kanneganti TD (2013) Unsolved mysteries in NLR biology. Front Immunol 4:285. doi:10.3389/fimmu.2013.00285

50. O'Connor W Jr, Harton JA, Zhu X, Linhoff MW, Ting JP (2003) Cutting edge: CIAS1/cryopyrin/PYPAF1/NALP3/CATERPILLER 1.1 is an inducible inflammatory mediator with NFkappa B suppressive properties. J Immunol 171:6329-6333. doi:10.4049/jimmunol.171.12.6329

51. Martinon F, Petrilli V, Mayor A, Tardivel A, Tschopp J (2006) Gout-associated uric acid crystals activate the NALP3 inflammasome. Nature 440:237-241. doi:10.1038/nature04516

52. Martinon F, Gaide O, Petrilli V, Mayor A, Tschopp J (2007) NALP inflammasomes: a central role in innate immunity. Semin Immunopathol 29:213-229. doi:10.1007/s00281-007-0079-y

53. Petrilli V, Dostert C, Muruve DA, Tschopp J (2007) The inflammasome: a danger sensing complex triggering innate immunity. Curr Opin Immunol 19:615-622. doi:10.1016/j.coi. 2007.09.002

54. Hornung V, Ablasser A, Charrel-Dennis M, Bauernfeind F, Horvath G, Caffrey DR, Latz E, Fitzgerald KA (2009) AIM2 recognizes cytosolic dsDNA and forms a caspase-1-activating inflammasome with ASC. Nature 458:514-518. doi:10.1038/ nature 07725

55. Fernandes-Alnemri T, Yu JW, Datta $\mathrm{P}, \mathrm{Wu}$ J, Alnemri ES (2009) AIM2 activates the inflammasome and cell death in response to cytoplasmic DNA. Nature 458:509-513. doi:10. 1038/nature07710

56. Burckstummer T, Baumann C, Bluml S, Dixit E, Durnberger G, Jahn H, Planyavsky M, Bilban M, Colinge J, Bennett KL, Superti-Furga G (2009) An orthogonal proteomic-genomic screen identifies AIM2 as a cytoplasmic DNA sensor for the inflammasome. Nat Immunol 10:266-272. doi:10.1038/ni.1702

57. Roberts TL, Idris A, Dunn JA, Kelly GM, Burnton CM, Hodgson S, Hardy LL, Garceau V, Sweet MJ, Ross IL, Hume DA, Stacey KJ (2009) HIN-200 proteins regulate caspase activation in response to foreign cytoplasmic DNA. Science 323:1057-1060. doi:10.1126/science.1169841

58. Takaoka A, Wang Z, Choi MK, Yanai H, Negishi H, Ban T, Lu Y, Miyagishi M, Kodama T, Honda K, Ohba Y, Taniguchi T (2007) DAI (DLM-1/ZBP1) is a cytosolic DNA sensor and an activator of innate immune response. Nature 448:501-505. doi:10.1038/nature06013

59. Unterholzner L, Keating SE, Baran M, Horan KA, Jensen SB, Sharma S, Sirois CM, Jin T, Latz E, Xiao TS, Fitzgerald KA, Paludan SR, Bowie AG (2010) IFI16 is an innate immune sensor for intracellular DNA. Nat Immunol 11:997-1004. doi:10.1038/ ni. 1932

60. Kerur N, Veettil MV, Sharma-Walia N, Bottero V, Sadagopan S, Otageri P, Chandran B (2011) IFI16 acts as a nuclear pathogen sensor to induce the inflammasome in response to Kaposi Sarcoma-associated herpesvirus infection. Cell Host Microbe 9:363-375. doi:10.1016/j.chom.2011.04.008

61. Ansari MA, Singh VV, Dutta S, Veettil MV, Dutta D, Chikoti L, Lu J, Everly D, Chandran B (2013) Constitutive interferon-inducible protein 16-inflammasome activation during Epstein-Barr 
virus latency I, II, and III in B and epithelial cells. J Virol 87:8606-8623. doi:10.1128/JVI.00805-13

62. Liao JC, Lam R, Brazda V, Duan S, Ravichandran M, Ma J, Xiao T, Tempel W, Zuo X, Wang YX, Chirgadze NY, Arrowsmith CH (2011) Interferon-inducible protein 16: insight into the interaction with tumor suppressor p53. Structure 19:418-429. doi:10.1016/j.str.2010.12.015

63. Yoneyama M, Kikuchi M, Natsukawa T, Shinobu N, Imaizumi T, Miyagishi M, Taira K, Akira S, Fujita T (2004) The RNA helicase RIG-I has an essential function in double-stranded RNA-induced innate antiviral responses. Nat Immunol 5:730-737. doi:10.1038/ni1087

64. Tarallo V, Hirano Y, Gelfand BD, Dridi S, Kerur N, Kim Y, Cho WG, Kaneko H, Fowler BJ, Bogdanovich S, Albuquerque RJ, Hauswirth WW, Chiodo VA, Kugel JF, Goodrich JA, Ponicsan SL, Chaudhuri G, Murphy MP, Dunaief JL, Ambati BK, Ogura Y, Yoo JW, Lee DK, Provost P, Hinton DR, Nunez G, Baffi JZ, Kleinman ME, Ambati J (2012) DICER1 loss and Alu RNA induce age-related macular degeneration via the NLRP3 inflammasome and MyD88. Cell 149:847-859. doi:10.1016/j. cell.2012.03.036

65. Doyle SL, Campbell M, Ozaki E, Salomon RG, Mori A, Kenna PF, Farrar GJ, Kiang AS, Humphries MM, Lavelle EC, O’Neill LA, Hollyfield JG, Humphries P (2012) NLRP3 has a protective role in age-related macular degeneration through the induction of IL-18 by drusen components. Nat Med 18:791-798. doi:10. 1038/nm.2717

66. Kauppinen A, Niskanen H, Suuronen T, Kinnunen K, Salminen A, Kaarniranta K (2012) Oxidative stress activates NLRP3 inflammasomes in ARPE-19 cells-implications for age-related macular degeneration (AMD). Immunol Lett 147:29-33. doi:10. 1016/j.imlet.2012.05.005

67. Anderson OA, Finkelstein A, Shima DT (2013) A2E induces IL$1 \beta$ production in retinal pigment epithelial cells via the NLRP3 inflammasome. PLoS One 8:e67263. doi:10.1371/journal.pone. 0067263

68. Liu RT, Gao J, Cao S, Sandhu N, Cui JZ, Chou CL, Fang E, Matsubara JA (2013) Inflammatory mediators induced by amyloid-beta in the retina and RPE in vivo: implications for inflammasome activation in age-related macular degeneration. Invest Ophthalmol Vis Sci 54:2225-2237. doi:10.1167/iovs.1210849

69. Zhao T, Gao J, Van J, To E, Wang A, Cao S, Cui JZ, Guo JP, Lee M, McGeer PL, Matsubara JA (2015) Age-related increases in amyloid beta and membrane attack complex: evidence of inflammasome activation in the rodent eye. J Neuroinflammation 12:121. doi:10.1186/s12974-015-0337-1

70. Triantafilou K, Hughes TR, Triantafilou M, Morgan BP (2013) The complement membrane attack complex triggers intracellular $\mathrm{Ca}^{2+}$ fluxes leading to NLRP3 inflammasome activation. J Cell Sci 126:2903-2913. doi:10.1242/jcs.124388

71. Brandstetter C, Mohr LK, Latz E, Holz FG, Krohne TU (2015) Light induces NLRP3 inflammasome activation in retinal pigment epithelial cells via lipofuscin-mediated photooxidative damage. J Mol Med (Berl) 93:905-916. doi:10.1007/s00109015-1275-1

72. Gelfand BD, Wright CB, Kim Y, Yasuma T, Yasuma R, Li S, Fowler BJ, Bastos-Carvalho A, Kerur N, Uittenbogaard A, Han YS, Lou D, Kleinman ME, McDonald WH, Nunez G, Georgel P, Dunaief JL, Ambati J (2015) Iron toxicity in the retina requires Alu RNA and the NLRP3 inflammasome. Cell Rep 11:1686-1693. doi:10.1016/j.celrep.2015.05.023

73. Blasiak J, Szaflik J, Szaflik JP (2011) Implications of altered iron homeostasis for age-related macular degeneration. Front Biosci (Landmark Ed) 16:1551-1559. doi:10.2741/3804
74. Shi G, Chen S, Wandu WS, Ogbeifun O, Nugent LF, Maminishkis A, Hinshaw SJ, Rodriguez IR, Gery I (2015) Inflammasomes induced by 7-ketocholesterol and other stimuli in RPE and in bone marrow-derived cells differ markedly in their production of IL-1beta and IL-18. Invest Ophthalmol Vis Sci 56:1658-1664. doi:10.1167/iovs.14-14557

75. Marneros AG (2013) NLRP3 inflammasome blockade inhibits VEGF-A-induced age-related macular degeneration. Cell Rep 4:945-958. doi:10.1016/j.celrep.2013.08.002

76. Tseng WA, Thein T, Kinnunen K, Lashkari K, Gregory MS, D'Amore PA, Ksander BR (2013) NLRP3 inflammasome activation in retinal pigment epithelial cells by lysosomal destabilization: implications for age-related macular degeneration. Invest Ophthalmol Vis Sci 54:110-120. doi:10.1167/iovs. 12-10655

77. Kerur N, Hirano Y, Tarallo V, Fowler BJ, Bastos-Carvalho A, Yasuma T, Yasuma R, Kim Y, Hinton DR, Kirschning CJ, Gelfand BD, Ambati J (2013) TLR-independent and P2X7-dependent signaling mediate Alu RNA-induced NLRP3 inflammasome activation in geographic atrophy. Invest Ophthalmol Vis Sci 54:7395-7401. doi:10.1167/iovs.13-12500

78. Hu SJ, Calippe B, Lavalette S, Roubeix C, Montassar F, Housset M, Levy O, Delarasse C, Paques M, Sahel JA, Sennlaub F, Guillonneau X (2015) Upregulation of P2RX7 in Cx3cr1-deficient mononuclear phagocytes leads to increased interleukin-1beta secretion and photoreceptor neurodegeneration. J Neurosci 35:6987-6996. doi:10.1523/JNEUROSCI. 3955-14.2015

79. Indaram M, Ma W, Zhao L, Fariss RN, Rodriguez IR, Wong WT (2015) 7-Ketocholesterol increases retinal microglial migration, activation, and angiogenicity: a potential pathogenic mechanism underlying age-related macular degeneration. Sci Rep 5:9144. doi:10.1038/srep09144

80. Kim B, Lee S, Suvas S, Rouse BT (2005) Application of plasmid DNA encoding IL-18 diminishes development of herpetic stromal keratitis by antiangiogenic effects. J Immunol 175:509-516. doi:10.4049/jimmunol.175.1.509

81. Qiao H, Sonoda KH, Ikeda Y, Yoshimura T, Hijioka K, Jo YJ, Sassa Y, Tsutsumi-Miyahara C, Hata Y, Akira S, Ishibashi T (2007) Interleukin-18 regulates pathological intraocular neovascularization. J Leukoc Biol 81:1012-1021. doi:10.1189/jlb. 0506342

82. Shen J, Choy DF, Yoshida T, Iwase T, Hafiz G, Xie B, Hackett SF, Arron JR, Campochiaro PA (2014) Interleukin-18 has antipermeablity and antiangiogenic activities in the eye; reciprocal suppression with VEGF. J Cell Physiol 229:974-983. doi: $10.1002 /$ jcp. 24575

83. Doyle SL, Ozaki E, Brennan K, Humphries MM, Mulfaul K, Keaney J, Kenna PF, Maminishkis A, Kiang AS, Saunders SP, Hams E, Lavelle EC, Gardiner C, Fallon PG, Adamson P, Humphries P, Campbell M (2014) IL-18 attenuates experimental choroidal neovascularization as a potential therapy for wet agerelated macular degeneration. Sci Transl Med 6:230ra44. doi:10. 1126/scitranslmed.3007616

84. Ijima R, Kaneko H, Ye F, Nagasaka Y, Takayama K, Kataoka K, Kachi S, Iwase T, Terasaki H (2014) Interleukin-18 induces retinal pigment epithelium degeneration in mice. Invest Ophthalmol Vis Sci 55:6673-6678. doi:10.1167/iovs.14-15367

85. Kim Y, Tarallo V, Kerur N, Yasuma T, Gelfand BD, BastosCarvalho A, Hirano Y, Yasuma R, Mizutani T, Fowler BJ, Li S, Kaneko H, Bogdanovich S, Ambati BK, Hinton DR, Hauswirth WW, Hakem R, Wright C, Ambati J (2014) DICER1/Alu RNA dysmetabolism induces Caspase-8-mediated cell death in agerelated macular degeneration. Proc Natl Acad Sci USA 111:16082-16087. doi:10.1073/pnas.1403814111 
86. Hirano Y, Yasuma T, Mizutani T, Fowler BJ, Tarallo V, Yasuma R, Kim Y, Bastos-Carvalho A, Kerur N, Gelfand BD, Bogdanovich S, He S, Zhang X, Nozaki M, Ijima R, Kaneko H, Ogura Y, Terasaki H, Nagai H, Haro I, Nunez G, Ambati BK, Hinton DR, Ambati J (2014) IL-18 is not therapeutic for neovascular age-related macular degeneration. Nat Med 20:1372-1375. doi:10.1038/nm.3671

87. Doyle SL, Adamson P, Lopez FJ, Humphries P, Campbell M (2014) Reply to IL-18 is not therapeutic for neovascular agerelated macular degeneration. Nat Med 20:1376-1377. doi:10. 1038/nm.3741

88. Doyle SL, Adamson P, Lopez FJ, Humphries P, Campbell M (2014) Interleukin-18 bioactivity and dose: data interpretation at a crossroads. Invest Ophthalmol Vis Sci 55:8349-8350. doi:10. 1167/iovs. 14-15786

89. Kaneko H (2014) Author response: interleukin-18 bioactivity and dose: data interpretation at a crossroads. Invest Ophthalmol Vis Sci 55:8350-8352. doi:10.1167/iovs.14-15878

90. Liu RT, Wang A, To E, Gao J, Cao S, Cui JZ, Matsubara JA (2014) Vinpocetine inhibits amyloid-beta induced activation of NF-kappaB, NLRP3 inflammasome and cytokine production in retinal pigment epithelial cells. Exp Eye Res 127:49-58. doi:10. 1016/j.exer.2014.07.003

91. Ildefonso CJ, Jaime H, Biswal MR, Boye SE, Li Q, Hauswirth WW, Lewin AS (2015) Gene therapy with the caspase activation and recruitment domain reduces the ocular inflammatory response. Mol Ther 23:875-884. doi:10.1038/mt.2015.30

92. Dunkelberger JR, Song WC (2010) Complement and its role in innate and adaptive immune responses. Cell Res 20:34-50. doi:10.1038/cr.2009.139

93. Hawlisch H, Kohl J (2006) Complement and Toll-like receptors: key regulators of adaptive immune responses. Mol Immunol 43:13-21. doi:10.1016/j.molimm.2005.06.028

94. Nilsson G, Johnell M, Hammer CH, Tiffany HL, Nilsson K, Metcalfe DD, Siegbahn A, Murphy PM (1996) C3a and C5a are chemotaxins for human mast cells and act through distinct receptors via a pertussis toxin-sensitive signal transduction pathway. J Immunol 157:1693-1698

95. DiScipio RG, Schraufstatter IU (2007) The role of the complement anaphylatoxins in the recruitment of eosinophils. Int Immunopharmacol 7:1909-1923. doi:10.1016/j.intimp.2007.07. 006

96. Daffern PJ, Pfeifer PH, Ember JA, Hugli TE (1995) C3a is a chemotaxin for human eosinophils but not for neutrophils. I. C3a stimulation of neutrophils is secondary to eosinophil activation. J Exp Med 181:2119-2127. doi:10.1084/jem.181.6.2119

97. Kildsgaard J, Hollmann TJ, Matthews KW, Bian K, Murad F, Wetsel RA (2000) Cutting edge: targeted disruption of the C3a receptor gene demonstrates a novel protective anti-inflammatory role for C3a in endotoxin-shock. J Immunol 165:5406-5409. doi:10.4049/jimmunol.165.10.5406

98. Asgari E, Le Friec G, Yamamoto H, Perucha E, Sacks SS, Kohl J, Cook HT, Kemper C (2013) C3a modulates IL-1beta secretion in human monocytes by regulating ATP efflux and subsequent NLRP3 inflammasome activation. Blood 122:3473-3481. doi:10.1182/blood-2013-05-502229

99. Laudisi F, Spreafico R, Evrard M, Hughes TR, Mandriani B, Kandasamy M, Morgan BP, Sivasankar B, Mortellaro A (2013) Cutting edge: the NLRP3 inflammasome links complementmediated inflammation and IL-1beta release. J Immunol 191:1006-1010. doi:10.4049/jimmunol.1300489

100. An LL, Mehta P, Xu L, Turman S, Reimer T, Naiman B, Connor J, Sanjuan M, Kolbeck R, Fung M (2014) Complement C5a potentiates uric acid crystal-induced IL-1beta production. Eur J Immunol 44:3669-3679. doi:10.1002/eji.201444560
101. Samstad EO, Niyonzima N, Nymo S, Aune MH, Ryan L, Bakke SS, Lappegard KT, Brekke OL, Lambris JD, Damas JK, Latz E, Mollnes TE, Espevik T (2014) Cholesterol crystals induce complement-dependent inflammasome activation and cytokine release. J Immunol 192:2837-2845. doi:10.4049/jimmunol. 1302484

102. Cumpelik A, Ankli B, Zecher D, Schifferli JA (2015) Neutrophil microvesicles resolve gout by inhibiting C5a-mediated priming of the inflammasome. Ann Rheum Dis. doi:10.1136/ annrheumdis-2015-207338

103. Agrawal A, Singh PP, Bottazzi B, Garlanda C, Mantovani A (2009) Pattern recognition by pentraxins. Adv Exp Med Biol 653:98-116. doi:10.1007/978-1-4419-0901-5

104. Deban L, Bottazzi B, Garlanda C, de la Torre YM, Mantovani A (2009) Pentraxins: multifunctional proteins at the interface of innate immunity and inflammation. Biofactors 35:138-145. doi:10.1002/biof.21

105. Mousavi M, Armstrong RA (2013) Genetic risk factors and agerelated macular degeneration (AMD). J Optom 6:176-184. doi:10.1016/j.optom.2013.07.002

106. Edwards AO, Ritter R 3rd, Abel KJ, Manning A, Panhuysen C, Farrer LA (2005) Complement factor $\mathrm{H}$ polymorphism and agerelated macular degeneration. Science 308:421-424. doi:10. 1126/science. 1110189

107. Haines JL, Hauser MA, Schmidt S, Scott WK, Olson LM, Gallins P, Spencer KL, Kwan SY, Noureddine M, Gilbert JR, Schnetz-Boutaud N, Agarwal A, Postel EA, Pericak-Vance MA (2005) Complement factor $\mathrm{H}$ variant increases the risk of agerelated macular degeneration. Science 308:419-421. doi:10. 1126/science. 1110359

108. Klein RJ, Zeiss C, Chew EY, Tsai JY, Sackler RS, Haynes C, Henning AK, SanGiovanni JP, Mane SM, Mayne ST, Bracken MB, Ferris FL, Ott J, Barnstable C, Hoh J (2005) Complement factor $\mathrm{H}$ polymorphism in age-related macular degeneration. Science 308:385-389. doi:10.1126/science.1109557

109. Hageman GS, Anderson DH, Johnson LV, Hancox LS, Taiber AJ, Hardisty LI, Hageman JL, Stockman HA, Borchardt JD, Gehrs KM, Smith RJ, Silvestri G, Russell SR, Klaver CC, Barbazetto I, Chang S, Yannuzzi LA, Barile GR, Merriam JC, Smith RT, Olsh AK, Bergeron J, Zernant J, Merriam JE, Gold B, Dean M, Allikmets R (2005) A common haplotype in the complement regulatory gene factor $\mathrm{H}(\mathrm{HF} 1 / \mathrm{CFH})$ predisposes individuals to age-related macular degeneration. Proc Natl Acad Sci USA 102:7227-7232. doi:10.1073/pnas.0501536 102

110. Horie-Inoue K, Inoue S (2014) Genomic aspects of age-related macular degeneration. Biochem Biophys Res Commun 452:263-275. doi:10.1016/j.bbrc.2014.08.013

111. Okemefuna AI, Nan R, Miller A, Gor J, Perkins SJ (2010) Complement factor $\mathrm{H}$ binds at two independent sites to $\mathrm{C}$-reactive protein in acute phase concentrations. J Biol Chem 285:1053-1065. doi:10.1074/jbc.M109.044529

112. Laine M, Jarva H, Seitsonen S, Haapasalo K, Lehtinen MJ, Lindeman N, Anderson DH, Johnson PT, Jarvela I, Jokiranta TS, Hageman GS, Immonen I, Meri S (2007) Y402H polymorphism of complement factor $\mathrm{H}$ affects binding affinity to C-reactive protein. J Immunol 178:3831-3836. doi:10.4049/jimmunol.178. 6.3831

113. Deban L, Jarva H, Lehtinen MJ, Bottazzi B, Bastone A, Doni A, Jokiranta TS, Mantovani A, Meri S (2008) Binding of the long pentraxin PTX3 to factor $\mathrm{H}$ : interacting domains and function in the regulation of complement activation. $\mathrm{J}$ Immunol 181:8433-8440. doi:10.4049/jimmunol.181.12.8433

114. Kaemmerer E, Schutt F, Krohne TU, Holz FG, Kopitz J (2007) Effects of lipid peroxidation-related protein modifications on 
RPE lysosomal functions and POS phagocytosis. Invest Ophthalmol Vis Sci 48:1342-1347. doi:10.1167/iovs.06-0549

115. Weismann D, Hartvigsen K, Lauer N, Bennett KL, Scholl HP, Charbel Issa P, Cano M, Brandstatter H, Tsimikas S, Skerka C, Superti-Furga G, Handa JT, Zipfel PF, Witztum JL, Binder CJ (2011) Complement factor $\mathrm{H}$ binds malondialdehyde epitopes and protects from oxidative stress. Nature 478:76-81. doi:10. 1038/nature 10449

116. Chen M, Forrester JV, Xu H (2007) Synthesis of complement factor $\mathrm{H}$ by retinal pigment epithelial cells is down-regulated by oxidized photoreceptor outer segments. Exp Eye Res 84:635-645. doi:10.1016/j.exer.2006.11.015

117. Wu Z, Lauer TW, Sick A, Hackett SF, Campochiaro PA (2007) Oxidative stress modulates complement factor $\mathrm{H}$ expression in retinal pigmented epithelial cells by acetylation of FOXO3. J Biol Chem 282:22414-22425. doi:10.1074/jbc.M702321200

118. Chen M, Muckersie E, Robertson M, Forrester JV, Xu H (2008) Up-regulation of complement factor $\mathrm{B}$ in retinal pigment epithelial cells is accompanied by complement activation in the aged retina. Exp Eye Res 87:543-550. doi:10.1016/j.exer.2008. 09.005

119. Kaarniranta K, Salminen A (2009) Age-related macular degeneration: activation of innate immunity system via pattern recognition receptors. J Mol Med (Berl) 87:117-123. doi:10. 1007/s00109-008-0418-z

120. Thurman JM, Renner B, Kunchithapautham K, Ferreira VP, Pangburn MK, Ablonczy Z, Tomlinson S, Holers VM, Rohrer B (2009) Oxidative stress renders retinal pigment epithelial cells susceptible to complement-mediated injury. J Biol Chem 284:16939-16947. doi:10.1074/jbc.M808166200

121. Kunchithapautham K, Atkinson C, Rohrer B (2014) Smoke exposure causes endoplasmic reticulum stress and lipid accumulation in retinal pigment epithelium through oxidative stress and complement activation. J Biol Chem 289:14534-14546. doi:10.1074/jbc.M114.564674

122. Aredo B, Li T, Chen X, Zhang K, Wang CX, Gou D, Zhao B, He Y, Ufret-Vincenty RL (2015) A chimeric Cfh transgene leads to increased retinal oxidative stress, inflammation, and accumulation of activated subretinal microglia in mice. Invest Ophthalmol Vis Sci 56:3427-3440. doi:10.1167/iovs.14-16089

123. Luo C, Zhao J, Madden A, Chen M, Xu H (2013) Complement expression in retinal pigment epithelial cells is modulated by activated macrophages. Exp Eye Res 112:93-101. doi:10.1016/j. exer.2013.04.016

124. Yates JR, Sepp T, Matharu BK, Khan JC, Thurlby DA, Shahid H, Clayton DG, Hayward C, Morgan J, Wright AF, Armbrecht AM, Dhillon B, Deary IJ, Redmond E, Bird AC, Moore AT, Genetic Factors in AMD Study Group (2007) Complement C3 variant and the risk of age-related macular degeneration. N Engl J Med 357:553-561. doi:10.1056/NEJMoa072618

125. Maller JB, Fagerness JA, Reynolds RC, Neale BM, Daly MJ, Seddon JM (2007) Variation in complement factor 3 is associated with risk of age-related macular degeneration. Nat Genet 39:1200-1201. doi:10.1038/ng2131

126. Seitsonen SP, Onkamo P, Peng G, Xiong M, Tommila PV, Ranta PH, Holopainen JM, Moilanen JA, Palosaari T, Kaarniranta K, Meri S, Immonen IR, Jarvela IE (2008) Multifactor effects and evidence of potential interaction between complement factor $\mathrm{H} \mathrm{Y} 402 \mathrm{H}$ and LOC387715 A69S in age-related macular degeneration. PLoS One 3:e3833. doi:10.1371/journal. pone. 0003833

127. Seddon JM, Yu Y, Miller EC, Reynolds R, Tan PL, Gowrisankar S, Goldstein JI, Triebwasser M, Anderson HE, Zerbib J, Kavanagh D, Souied E, Katsanis N, Daly MJ, Atkinson JP, Raychaudhuri S (2013) Rare variants in CFI, C3 and $\mathrm{C} 9$ are associated with high risk of advanced age-related macular degeneration. Nat Genet 45:1366-1370. doi:10.1038/ ng.2741

128. van de Ven JP, Nilsson SC, Tan PL, Buitendijk GH, Ristau T, Mohlin FC, Nabuurs SB, Schoenmaker-Koller FE, Smailhodzic D, Campochiaro PA, Zack DJ, Duvvari MR, Bakker B, Paun CC, Boon CJ, Uitterlinden AG, Liakopoulos S, Klevering BJ, Fauser S, Daha MR, Katsanis N, Klaver CC, Blom AM, Hoyng CB, den Hollander AI (2013) A functional variant in the CFI gene confers a high risk of age-related macular degeneration. Nat Genet 45:813-817. doi:10.1038/ng.2640

129. Zhan X, Larson DE, Wang C, Koboldt DC, Sergeev YV, Fulton RS, Fulton LL, Fronick CC, Branham KE, Bragg-Gresham J, Jun G, Hu Y, Kang HM, Liu D, Othman M, Brooks M, Ratnapriya $\mathrm{R}$, Boleda $\mathrm{A}$, Grassmann $\mathrm{F}$, von Strachwitz C, Olson LM, Buitendijk GH, Hofman A, van Duijn CM, Cipriani V, Moore AT, Shahid H, Jiang Y, Conley YP, Morgan DJ, Kim IK, Johnson MP, Cantsilieris S, Richardson AJ, Guymer RH, Luo H, Ouyang H, Licht C, Pluthero FG, Zhang MM, Zhang K, Baird PN, Blangero J, Klein ML, Farrer LA, DeAngelis MM, Weeks DE, Gorin MB, Yates JR, Klaver CC, Pericak-Vance MA, Haines JL, Weber BH, Wilson RK, Heckenlively JR, Chew EY, Stambolian D, Mardis ER, Swaroop A, Abecasis GR (2013) Identification of a rare coding variant in complement 3 associated with age-related macular degeneration. Nat Genet 45:1375-1379. doi:10.1038/ng.2758

130. Alexander P, Gibson J, Cree AJ, Ennis S, Lotery AJ (2014) Complement factor I and age-related macular degeneration. Mol Vis 20:1253-1257

131. Gibson J, Cree A, Collins A, Lotery A, Ennis S (2010) Determination of a gene and environment risk model for age-related macular degeneration. Br J Ophthalmol 94:1382-1387. doi:10. 1136/bjo.2010.182568

132. Tanaka K, Nakayama T, Mori R, Sato N, Kawamura A, Yuzawa M (2014) Associations of complement factor B and complement component 2 genotypes with subtypes of polypoidal choroidal vasculopathy. BMC Ophthalmol 14:83. doi:10.1186/1471-2415$14-83$

133. Schnabolk G, Coughlin B, Joseph K, Kunchithapautham K, Bandyopadhyay M, O'Quinn EC, Nowling T, Rohrer B (2015) Local production of the alternative pathway component factor $\mathrm{B}$ is sufficient to promote laser-induced choroidal neovascularization. Invest Ophthalmol Vis Sci 56:1850-1863. doi:10.1167/ iovs.14-15910

134. Gold B, Merriam JE, Zernant J, Hancox LS, Taiber AJ, Gehrs K, Cramer K, Neel J, Bergeron J, Barile GR, Smith RT, AMD Genetics Clinical Study Group, Hageman GS, Dean M, Allikmets R (2006) Variation in factor B (BF) and complement component $2(\mathrm{C} 2)$ genes is associated with age-related macular degeneration. Nat Genet 38:458-462. doi:10.1038/ng 1750

135. Spencer KL, Hauser MA, Olson LM, Schmidt S, Scott WK, Gallins P, Agarwal A, Postel EA, Pericak-Vance MA, Haines JL (2007) Protective effect of complement factor B and complement component 2 variants in age-related macular degeneration. Hum Mol Genet 16:1986-1992. doi:10.1093/hmg/ddm146

136. Thakkinstian A, McEvoy M, Chakravarthy U, Chakrabarti S, McKay GJ, Ryu E, Silvestri G, Kaur I, Francis P, Iwata T, Akahori M, Arning A, Edwards AO, Seddon JM, Attia J (2012) The association between complement component $2 /$ complement factor B polymorphisms and age-related macular degeneration: a HuGE review and meta-analysis. Am $J$ Epidemiol 176:361-372. doi:10.1093/aje/kws031

137. Wang X, Zhang Y, Zhang MN (2013) Complement factor B polymorphism (rs641153) and susceptibility to age-related macular degeneration: evidence from published studies. Int $\mathbf{J}$ Ophthalmol 6:861-867. doi:10.3980/j.issn.2222-3959.2013.06. 21 
138. Nozaki M, Raisler BJ, Sakurai E, Sarma JV, Barnum SR, Lambris JD, Chen Y, Zhang K, Ambati BK, Baffi JZ, Ambati J (2006) Drusen complement components C3a and C5a promote choroidal neovascularization. Proc Natl Acad Sci USA 103:2328-2333. doi:10.1073/pnas.0408835103

139. Bora NS, Kaliappan S, Jha P, Xu Q, Sivasankar B, Harris CL, Morgan BP, Bora PS (2007) CD59, a complement regulatory protein, controls choroidal neovascularization in a mouse model of wet-type age-related macular degeneration. J Immunol 178:1783-1790. doi:10.4049/jimmunol.178.3.1783

140. Cashman SM, Ramo K, Kumar-Singh R (2011) A non membrane-targeted human soluble CD59 attenuates choroidal neovascularization in a model of age related macular degeneration. PLoS One 6:e19078. doi:10.1371/journal.pone.0019078

141. Joseph K, Kulik L, Coughlin B, Kunchithapautham K, Bandyopadhyay M, Thiel S, Thielens NM, Holers VM, Rohrer B (2013) Oxidative stress sensitizes retinal pigmented epithelial (RPE) cells to complement-mediated injury in a natural antibody-, lectin pathway-, and phospholipid epitope-dependent manner. J Biol Chem 288:12753-12765. doi:10.1074/jbc.M112. 421891

142. Fernandez-Godino R, Garland DL, Pierce EA (2015) A local complement response by RPE causes early-stage macular degeneration. Hum Mol Genet 24:5555-5559. doi:10.1093/hmg/ ddv287

143. Wang J, Ohno-Matsui K, Yoshida T, Shimada N, Ichinose S, Sato T, Mochizuki M, Morita I (2009) Amyloid-beta up-regulates complement factor B in retinal pigment epithelial cells through cytokines released from recruited macrophages/microglia: another mechanism of complement activation in agerelated macular degeneration. J Cell Physiol 220:119-128. doi:10.1002/jcp. 21742

144. Wang L, Kondo N, Cano M, Ebrahimi K, Yoshida T, Barnett BP, Biswal S, Handa JT (2014) Nrf2 signaling modulates cigarette smoke-induced complement activation in retinal pigmented epithelial cells. Free Radic Biol Med 70:155-166. doi:10.1016/j.freeradbiomed.2014.01.015

145. Liu B, Wei L, Meyerle C, Tuo J, Sen HN, Li Z, Chakrabarty S, Agron E, Chan CC, Klein ML, Chew E, Ferris F, Nussenblatt RB (2011) Complement component C5a promotes expression of IL-22 and IL-17 from human T cells and its implication in agerelated macular degeneration. J Transl Med 9:1-12. doi:10. 1186/1479-5876-9-111

146. Wei L, Liu B, Tuo J, Shen D, Chen P, Li Z, Liu X, Ni J, Dagur P, Sen HN, Jawad S, Ling D, Park S, Chakrabarty S, Meyerle C, Agron E, Ferris FL 3rd, Chew EY, McCoy JP, Blum E, Francis PJ, Klein ML, Guymer RH, Baird PN, Chan CC, Nussenblatt RB (2012) Hypomethylation of the IL17RC promoter associates with age-related macular degeneration. Cell Rep 2:1151-1158. doi:10.1016/j.celrep.2012.10.013

147. Ardeljan D, Wang Y, Park S, Shen D, Chu XK, Yu CR, AbuAsab M, Tuo J, Eberhart CG, Olsen TW, Mullins RF, White G, Wadsworth S, Scaria A, Chan CC (2014) Interleukin-17 retinotoxicity is prevented by gene transfer of a soluble interleukin-17 receptor acting as a cytokine blocker: implications for age-related macular degeneration. PLoS One 9:e95900. doi:10. 1371/journal.pone.0095900

148. Chen Y, Zhong M, Liang L, Gu F, Peng H (2014) Interleukin-17 induces angiogenesis in human choroidal endothelial cells in vitro. Invest Ophthalmol Vis Sci 55:6968-6975. doi:10.1167/ iovs.14-15029

149. Zhang S, Liu Y, Lu S, Cai X (2015) Genetic variants of interleukin $17 \mathrm{~A}$ are functionally associated with increased risk of age-related macular degeneration. Inflammation 38:658-663. doi:10.1007/s10753-014-9973-3
150. Zhang M, Xu G, Liu W, Ni Y, Zhou W (2012) Role of fractalkine/CX3CR1 interaction in light-induced photoreceptor degeneration through regulating retinal microglial activation and migration. PLoS One 7:e35446. doi:10.1371/journal.pone. 0035446

151. Faure S, Meyer L, Costagliola D, Vaneensberghe C, Genin E, Autran B, Delfraissy JF, McDermott DH, Murphy PM, Debre P, Theodorou I, Combadiere C (2000) Rapid progression to AIDS in HIV+ individuals with a structural variant of the chemokine receptor CX3CR1. Science 287:2274-2277. doi:10.1126/ science.287.5461.2274

152. Tuo J, Bojanowski CM, Zhou M, Shen D, Ross RJ, Rosenberg KI, Cameron DJ, Yin C, Kowalak JA, Zhuang Z, Zhang K, Chan CC (2007) Murine ccl2/cx3cr1 deficiency results in retinal lesions mimicking human age-related macular degeneration. Invest Ophthalmol Vis Sci 48:3827-3836. doi:10.1167/iovs.070051

153. Ross RJ, Zhou M, Shen D, Fariss RN, Ding X, Bojanowski CM, Tuo J, Chan CC (2008) Immunological protein expression profile in $\mathrm{Ccl} 2 / \mathrm{Cx} 3 \mathrm{cr} 1$ deficient mice with lesions similar to agerelated macular degeneration. Exp Eye Res 86:675-683. doi:10. 1016/j.exer.2008.01.014

154. Chen M, Hombrebueno JR, Luo C, Penalva R, Zhao J, Colhoun L, Pandi SP, Forrester JV, Xu H (2013) Age- and light-dependent development of localised retinal atrophy in CCL2(-/-)CX3CR1(GFP/GFP) mice. PLoS One 8:e61381. doi:10.1371/journal.pone.0061381

155. Sennlaub F, Auvynet C, Calippe B, Lavalette S, Poupel L, Hu SJ, Dominguez E, Camelo S, Levy O, Guyon E, Saederup N, Charo IF, Rooijen NV, Nandrot E, Bourges JL, Behar-Cohen F, Sahel JA, Guillonneau X, Raoul W, Combadiere C (2013) CCR2(+) monocytes infiltrate atrophic lesions in age-related macular disease and mediate photoreceptor degeneration in experimental subretinal inflammation in $\mathrm{Cx} 3 \mathrm{cr} 1$ deficient mice. EMBO Mol Med 5:1775-1793. doi:10.1002/emmm.201302 692

156. Liang KJ, Lee JE, Wang YD, Ma W, Fontainhas AM, Fariss RN, Wong WT (2009) Regulation of dynamic behavior of retinal microglia by CX3CR1 signaling. Invest Ophthalmol Vis Sci 50:4444-4451. doi:10.1167/iovs.08-3357

157. Medzhitov R (2008) Origin and physiological roles of inflammation. Nature 454:428-435. doi:10.1038/nature07201

158. Xu H, Chen M, Forrester JV (2009) Para-inflammation in the aging retina. Prog Retin Eye Res 28:348-368. doi:10.1016/j. preteyeres.2009.06.001

159. McDermott DH, Fong AM, Yang Q, Sechler JM, Cupples LA, Merrell MN, Wilson PW, D'Agostino RB, O'Donnell CJ, Patel DD, Murphy PM (2003) Chemokine receptor mutant CX3CR1M280 has impaired adhesive function and correlates with protection from cardiovascular disease in humans. J Clin Invest 111:1241-1250. doi:10.1172/JCI16790

160. Daoudi M, Lavergne E, Garin A, Tarantino N, Debre P, Pincet F, Combadiere C, Deterre P (2004) Enhanced adhesive capacities of the naturally occurring Ile249-Met280 variant of the chemokine receptor CX3CR1. J Biol Chem 279:19649-19657. doi:10.1074/jbc.M313457200

161. Chan CC, Tuo J, Bojanowski CM, Csaky KG, Green WR (2005) Detection of CX3CR1 single nucleotide polymorphism and expression on archived eyes with age-related macular degeneration. Histol Histopathol 20:857-863

162. Yang X, Hu J, Zhang J, Guan H (2010) Polymorphisms in CFH, HTRA1 and CX3CR1 confer risk to exudative age-related macular degeneration in Han Chinese. $\mathrm{Br} \mathrm{J}$ Ophthalmol 94:1211-1214. doi:10.1136/bjo.2009.165811 
163. Vessey KA, Greferath U, Jobling AI, Phipps JA, Ho T, Waugh M, Fletcher EL (2012) Ccl2/Cx3cr1 knockout mice have inner retinal dysfunction but are not an accelerated model of AMD. Invest Ophthalmol Vis Sci 53:7833-7846. doi:10.1167/iovs.1210650

164. Luhmann UF, Carvalho LS, Robbie SJ, Cowing JA, Duran Y, Munro PM, Bainbridge JW, Ali RR (2013) Ccl2, Cx3cr1 and $\mathrm{Ccl} / \mathrm{Cx} 3 \mathrm{cr} 1$ chemokine deficiencies are not sufficient to cause age-related retinal degeneration. Exp Eye Res 107:80-87. doi:10.1016/j.exer.2012.11.015

165. Schaumberg DA, Rose L, DeAngelis MM, Semba RD, Hageman GS, Chasman DI (2014) Prospective study of common variants in $\mathrm{CX} 3 \mathrm{CR} 1$ and risk of macular degeneration: pooled analysis from 5 long-term studies. JAMA Ophthalmol 132:84-95. doi:10.1001/jamaophthalmol.2013.5506

166. Luhmann UF, Lange CA, Robbie S, Munro PM, Cowing JA, Armer HE, Luong V, Carvalho LS, MacLaren RE, Fitzke FW, Bainbridge JW, Ali RR (2012) Differential modulation of retinal degeneration by $\mathrm{Ccl} 2$ and $\mathrm{Cx} 3 \mathrm{cr} 1$ chemokine signalling. PLoS One 7:e35551. doi:10.1371/journal.pone.0035551

167. Mattapallil MJ, Wawrousek EF, Chan CC, Zhao H, Roychoudhury J, Ferguson TA, Caspi RR (2012) The Rd8 mutation of the Crb1 gene is present in vendor lines of C57BL/6N mice and embryonic stem cells, and confounds ocular induced mutant phenotypes. Invest Ophthalmol Vis Sci 53:2921-2927. doi:10. 1167/iovs. 12-9662

168. Ramkumar HL, Tuo J, de Shen F, Zhang J, Cao X, Chew EY, Chan CC (2013) Nutrient supplementation with n3 polyunsaturated fatty acids, lutein, and zeaxanthin decrease $\mathrm{A} 2 \mathrm{E}$ accumulation and VEGF expression in the retinas of $\mathrm{Ccl} 2 /$ Cx3cr1-deficient mice on Crb1rd8 background. J Nutr 143:1129-1135. doi:10.3945/jn.112.169649

169. Zhang J, Tuo J, Cao X, Shen D, Li W, Chan CC (2013) Early degeneration of photoreceptor synapse in $\mathrm{Ccl} 2 / \mathrm{Cx} 3 \mathrm{cr} 1$-deficient mice on Crb1(rd8) background. Synapse 67:515-531. doi:10. 1002/syn.21674

170. Luhmann UF, Robbie S, Munro PM, Barker SE, Duran Y, Luong V, Fitzke FW, Bainbridge JW, Ali RR, MacLaren RE (2009) The drusenlike phenotype in aging Ccl2-knockout mice is caused by an accelerated accumulation of swollen autofluorescent subretinal macrophages. Invest Ophthalmol Vis Sci 50:5934-5943. doi:10.1167/iovs.09-3462

171. Chen M, Forrester JV, Xu H (2011) Dysregulation in retinal para-inflammation and age-related retinal degeneration in CCL2 or CCR2 deficient mice. PLoS One 6:e22818. doi:10.1371/ journal.pone.0022818

172. Despriet DD, Bergen AA, Merriam JE, Zernant J, Barile GR, Smith RT, Barbazetto IA, van Soest S, Bakker A, de Jong PT, Allikmets R, Klaver CC (2008) Comprehensive analysis of the candidate genes CCL2, CCR2, and TLR4 in age-related macular degeneration. Invest Ophthalmol Vis Sci 49:364-371. doi:10. 1167/iovs.07-0656

173. Lentsch AB, Ward PA (2000) Regulation of inflammatory vascular damage. J Pathol 190:343-348. doi:10.1002/(SICI)10969896(200002)190:3<343:AID-PATH522>3.0.CO;2-M

174. Blann AD (2000) Endothelial cell activation, injury, damage and dysfunction: separate entities or mutual terms? Blood Coagul Fibrinolysis 11:623-630. doi:10.1097/00001721-20001000000006

175. Sprague AH, Khalil RA (2009) Inflammatory cytokines in vascular dysfunction and vascular disease. Biochem Pharmacol 78:539-552. doi:10.1016/j.bcp.2009.04.029

176. Weber C, Fraemohs L, Dejana E (2007) The role of junctional adhesion molecules in vascular inflammation. Nat Rev Immunol 7:467-477. doi:10.1038/nri2096
177. Rather LJ (1971) Disturbance of function (functio laesa): the legendary fifth cardinal sign of inflammation, added by Galen to the four cardinal signs of Celsus. Bull N Y Acad Med 47:303-322

178. Mitchinson MJ (1989) Fluor: another cardinal sign of inflammation. Lancet 2:1520. doi:10.1016/S0140-6736(89)92957-7

179. Baggiolini M, Loetscher P, Moser B (1995) Interleukin-8 and the chemokine family. Int J Immunopharmacol 17:103-108. doi:10.1016/0192-0561(94)00088-6

180. Kobayashi Y (2008) The role of chemokines in neutrophil biology. Front Biosci 13:2400-2407. doi:10.2741/2853

181. Brinkmann V, Reichard U, Goosmann C, Fauler B, Uhlemann Y, Weiss DS, Weinrauch Y, Zychlinsky A (2004) Neutrophil extracellular traps kill bacteria. Science 303:1532-1535. doi:10. 1126/science. 1092385

182. Mayadas TN, Cullere X, Lowell CA (2014) The multifaceted functions of neutrophils. Annu Rev Pathol 9:181-218. doi:10. 1146/annurev-pathol-020712-164023

183. Cui BB, Tan CY, Schorn C, Tang HH, Liu Y, Zhao Y (2012) Neutrophil extracellular traps in sterile inflammation: the story after dying? Autoimmunity 45:593-596. doi:10.3109/08916934. 2012.719952

184. Mantovani A, Cassatella MA, Costantini C, Jaillon S (2011) Neutrophils in the activation and regulation of innate and adaptive immunity. Nat Rev Immunol 11:519-531. doi:10.1038/ nri3024

185. Ohki Y, Heissig B, Sato Y, Akiyama H, Zhu Z, Hicklin DJ, Shimada K, Ogawa H, Daida H, Hattori K, Ohsaka A (2005) Granulocyte colony-stimulating factor promotes neovascularization by releasing vascular endothelial growth factor from neutrophils. FASEB J 19:2005-2007. doi:10.1096/fj.04-3496fje

186. Shi C, Pamer EG (2011) Monocyte recruitment during infection and inflammation. Nat Rev Immunol 11:762-774. doi:10.1038/ nri3070

187. Swirski FK, Robbins CS (2013) Neutrophils usher monocytes into sites of inflammation. Circ Res 112:744-745. doi:10.1161/ CIRCRESAHA.113.300867

188. Shi Y, Zheng W, Rock KL (2000) Cell injury releases endogenous adjuvants that stimulate cytotoxic $\mathrm{T}$ cell responses. Proc Natl Acad Sci USA 97:14590-14595. doi:10.1073/pnas. 260497597

189. Shi Y, Rock KL (2002) Cell death releases endogenous adjuvants that selectively enhance immune surveillance of particulate antigens. Eur J Immunol 32:155-162. doi:10.1002/ 1521-4141(200201)32:1<155:AID-IMMU155>3.0.CO;2-P

190. Pawelec G, Goldeck D, Derhovanessian E (2014) Inflammation, ageing and chronic disease. Curr Opin Immunol 29C:23-28. doi:10.1016/j.coi.2014.03.007

191. Mosser DM, Edwards JP (2008) Exploring the full spectrum of macrophage activation. Nat Rev Immunol 8:958-969. doi:10. 1038/nri2448

192. Mosser DM (2003) The many faces of macrophage activation. J Leukoc Biol 73:209-212. doi:10.1189/jlb.0602325

193. Fernandez-Velasco M, Gonzalez-Ramos S, Bosca L (2014) Involvement of monocytes/macrophages as key factors in the development and progression of cardiovascular diseases. Biochem J 458:187-193. doi:10.1042/BJ20131501

194. Gordon S, Martinez FO (2010) Alternative activation of macrophages: mechanism and functions. Immunity 32:593-604. doi:10.1016/j.immuni.2010.05.007

195. Zhao H, Roychoudhury J, Doggett TA, Apte RS, Ferguson TA (2013) Age-dependent changes in FasL (CD95L) modulate macrophage function in a model of age-related macular degeneration. Invest Ophthalmol Vis Sci 54:5321-5331. doi:10.1167/ iovs.13-12122 
196. Edwards JP, Zhang X, Frauwirth KA, Mosser DM (2006) Biochemical and functional characterization of three activated macrophage populations. J Leukoc Biol 80:1298-1307. doi:10. $1189 / \mathrm{jlb} .0406249$

197. Vallejo AN (2005) CD28 extinction in human T cells: altered functions and the program of T-cell senescence. Immunol Rev 205:158-169. doi:10.1111/j.0105-2896.2005.00256.x

198. Frasca D, Blomberg BB (2011) Aging affects human B cell responses. J Clin Immunol 31:430-435. doi:10.1007/s10875010-9501-7

199. Aspinall R, Lapenna A, B-Lynch C, Lang PO (2014) Cellular signalling pathways in immune aging and regeneration. Biochem Soc Trans 42:651-656. doi:10.1042/BST20140021

200. Lemster BH, Michel JJ, Montag DT, Paat JJ, Studenski SA, Newman AB, Vallejo AN (2008) Induction of CD56 and TCRindependent activation of $\mathrm{T}$ cells with aging. $\mathrm{J}$ Immunol 180:1979-1990. doi:10.4049/jimmunol.180.3.1979

201. Shaw AC, Goldstein DR, Montgomery RR (2013) Age-dependent dysregulation of innate immunity. Nat Rev Immunol 13:875-887. doi:10.1038/nri3547

202. Aprahamian T, Takemura Y, Goukassian D, Walsh K (2008) Ageing is associated with diminished apoptotic cell clearance in vivo. Clin Exp Immunol 152:448-455. doi:10.1111/j.13652249.2008.03658.x

203. Bird AC, Bressler NM, Bressler SB, Chisholm IH, Coscas G, Davis MD, de Jong PT, Klaver CC, Klein BE, Klein R, The International ARM Epidemiological Study Group (1995) An international classification and grading system for age-related maculopathy and age-related macular degeneration. Surv Ophthalmol 39:367-374. doi:10.1016/S0039-6257(05)80092-X

204. Sallo FB, Peto T, Leung I, Xing W, Bunce C, Bird AC (2009) The International Classification system and the progression of age-related macular degeneration. Curr Eye Res 34:238-240. doi:10.1080/02713680802714058

205. Fraccaro P, Nicolo M, Bonetto M, Giacomini M, Weller P, Traverso CE, Prosperi M, O Sullivan D (2015) Combining macula clinical signs and patient characteristics for age-related macular degeneration diagnosis: a machine learning approach. BMC Ophthalmol 15:10. doi:10.1186/1471-2415-15-10

206. Mullins RF, Russell SR, Anderson DH, Hageman GS (2000) Drusen associated with aging and age-related macular degeneration contain proteins common to extracellular deposits associated with atherosclerosis, elastosis, amyloidosis, and dense deposit disease. FASEB J 14:835-846

207. Ohno-Matsui K (2011) Parallel findings in age-related macular degeneration and Alzheimer's disease. Prog Retin Eye Res 30:217-238. doi:10.1016/j.preteyeres.2011.02.004

208. Burns RP, Feeney-Burns L (1980) Clinico-morphologic correlations of drusen of Bruch's membrane. Trans Am Ophthalmol Soc 78:206-225

209. Ishibashi T, Patterson R, Ohnishi Y, Inomata H, Ryan SJ (1986) Formation of drusen in the human eye. Am $\mathbf{J}$ Ophthalmol 101:342-353. doi:10.1016/0002-9394(86)90830-5

210. Hageman GS, Mullins RF, Russell SR, Johnson LV, Anderson DH (1999) Vitronectin is a constituent of ocular drusen and the vitronectin gene is expressed in human retinal pigmented epithelial cells. FASEB J 13:477-484

211. Ozaki S, Johnson LV, Mullins RF, Hageman GS, Anderson DH (1999) The human retina and retinal pigment epithelium are abundant sources of vitronectin mRNA. Biochem Biophys Res Commun 258:524-529. doi:10.1006/bbrc.1999.0672

212. Anderson DH, Mullins RF, Hageman GS, Johnson LV (2002) A role for local inflammation in the formation of drusen in the aging eye. Am J Ophthalmol 134:411-431. doi:10.1016/S00029394(02)01624-0
213. Crabb JW, Miyagi M, Gu X, Shadrach K, West KA, Sakaguchi H, Kamei M, Hasan A, Yan L, Rayborn ME, Salomon RG, Hollyfield JG (2002) Drusen proteome analysis: an approach to the etiology of age-related macular degeneration. Proc Natl Acad Sci USA 99:14682-14687. doi:10.1073/pnas.222551899

214. Sakaguchi H, Miyagi M, Shadrach KG, Rayborn ME, Crabb JW, Hollyfield JG (2002) Clusterin is present in drusen in age-related macular degeneration. Exp Eye Res 74:547-549. doi:10.1006/ exer.2002.1186

215. Anderson DH, Talaga KC, Rivest AJ, Barron E, Hageman GS, Johnson LV (2004) Characterization of beta amyloid assemblies in drusen: the deposits associated with aging and age-related macular degeneration. Exp Eye Res 78:243-256. pii:S0014483503003440

216. An E, Lu X, Flippin J, Devaney JM, Halligan B, Hoffman EP, Strunnikova N, Csaky K, Hathout Y (2006) Secreted proteome profiling in human RPE cell cultures derived from donors with age related macular degeneration and age matched healthy donors. J Proteome Res 5:2599-2610. doi:10.1021/pr060121j

217. Johnson LV, Forest DL, Banna CD, Radeke CM, Maloney MA, Hu J, Spencer CN, Walker AM, Tsie MS, Bok D, Radeke MJ, Anderson DH (2011) Cell culture model that mimics drusen formation and triggers complement activation associated with age-related macular degeneration. Proc Natl Acad Sci USA 108:18277-18282. doi:10.1073/pnas.1109703108

218. Ebrahimi KB, Handa JT (2011) Lipids, lipoproteins, and agerelated macular degeneration. J Lipids 2011:802059. doi:10. $1155 / 2011 / 802059$

219. Wang AL, Lukas TJ, Yuan M, Du N, Tso MO, Neufeld AH (2009) Autophagy and exosomes in the aged retinal pigment epithelium: possible relevance to drusen formation and age-related macular degeneration. PLoS One 4:e4160. doi:10.1371/ journal.pone. 0004160

220. Krohne TU, Holz FG, Kopitz J (2010) Apical-to-basolateral transcytosis of photoreceptor outer segments induced by lipid peroxidation products in human retinal pigment epithelial cells. Invest Ophthalmol Vis Sci 51:553-560. doi:10.1167/iovs.093755

221. Hageman GS, Luthert PJ, Victor Chong NH, Johnson LV, Anderson DH, Mullins RF (2001) An integrated hypothesis that considers drusen as biomarkers of immune-mediated processes at the RPE-Bruch's membrane interface in aging and age-related macular degeneration. Prog Retin Eye Res 20:705-732. doi:10. 1016/S1350-9462(01)00010-6

222. Johnson LV, Ozaki S, Staples MK, Erickson PA, Anderson DH (2000) A potential role for immune complex pathogenesis in drusen formation. Exp Eye Res 70:441-449. doi:10.1006/exer. 1999.0798

223. Johnson LV, Leitner WP, Staples MK, Anderson DH (2001) Complement activation and inflammatory processes in Drusen formation and age related macular degeneration. Exp Eye Res 73:887-896. doi:10.1006/exer.2001.1094

224. Johnson LV, Leitner WP, Rivest AJ, Staples MK, Radeke MJ, Anderson DH (2002) The Alzheimer's A beta -peptide is deposited at sites of complement activation in pathologic deposits associated with aging and age-related macular degeneration. Proc Natl Acad Sci USA 99:11830-11835. doi:10.1073/ pnas. 192203399

225. Anderson DH, Radeke MJ, Gallo NB, Chapin EA, Johnson PT, Curletti CR, Hancox LS, Hu J, Ebright JN, Malek G, Hauser MA, Rickman CB, Bok D, Hageman GS, Johnson LV (2010) The pivotal role of the complement system in aging and age-related macular degeneration: hypothesis re-visited. Prog Retin Eye Res 29:95-112. doi:10.1016/j.preteyeres. 2009.11.003 
226. Gehrs KM, Jackson JR, Brown EN, Allikmets R, Hageman GS (2010) Complement, age-related macular degeneration and a vision of the future. Arch Ophthalmol 128:349-358. doi:10. 1001/archophthalmol.2010.18

227. Liu C, Cao L, Yang S, Xu L, Liu P, Wang F, Xu D (2015) Subretinal injection of amyloid-beta peptide accelerates RPE cell senescence and retinal degeneration. Int $\mathrm{J}$ Mol Med 35:169-176. doi:10.3892/ijmm.2014.1993

228. Chen L, Yang P, Kijlstra A (2002) Distribution, markers, and functions of retinal microglia. Ocul Immunol Inflamm 10:27-39. doi:10.1076/ocii.10.1.27.10328

229. Xu H, Chen M, Manivannan A, Lois N, Forrester JV (2008) Age-dependent accumulation of lipofuscin in perivascular and subretinal microglia in experimental mice. Aging Cell 7:58-68. doi:10.1111/j.1474-9726.2007.00351.x

230. Griffith TS, Brunner T, Fletcher SM, Green DR, Ferguson TA (1995) Fas ligand-induced apoptosis as a mechanism of immune privilege. Science 270:1189-1192. doi:10.1126/science.270. 5239.1189

231. Griffith TS, Yu X, Herndon JM, Green DR, Ferguson TA (1996) CD95-induced apoptosis of lymphocytes in an immune privileged site induces immunological tolerance. Immunity 5:7-16. doi:10.1016/S1074-7613(00)80305-2

232. Elzey BD, Griffith TS, Herndon JM, Barreiro R, Tschopp J, Ferguson TA (2001) Regulation of Fas ligand-induced apoptosis by TNF. J Immunol 167:3049-3056. doi:10.4049/jimmunol.167. 6.3049

233. Ferguson TA, Green DR (2001) Fas-ligand and immune privilege: the eyes have it. Cell Death Differ 8:771-772. doi:10.1038/ sj.cdd.4400891

234. Roychoudhury J, Herndon JM, Yin J, Apte RS, Ferguson TA (2010) Targeting immune privilege to prevent pathogenic neovascularization. Invest Ophthalmol Vis Sci 51:3560-3566. doi:10.1167/iovs.09-3890

235. Ardeljan D, Chan CC (2013) Aging is not a disease: distinguishing age-related macular degeneration from aging. Prog Retin Eye Res 37:68-69. doi:10.1016/j.preteyeres.2013.07.003

236. Nita M, Grzybowski A, Ascaso FJ, Huerva V (2014) Age-related macular degeneration in the aspect of chronic low-grade inflammation (pathophysiological parainflammation). Mediators Inflamm 2014:930671. doi:10.1155/2014/930671

237. Wu WK, Llewellyn OP, Bates DO, Nicholson LB, Dick AD (2010) IL-10 regulation of macrophage VEGF production is dependent on macrophage polarisation and hypoxia. Immunobiology 215:796-803. doi:10.1016/j.imbio.2010.05.025

238. Faber C, Singh A, Kruger Falk M, Juel HB, Sorensen TL, Nissen MH (2013) Age-related macular degeneration is associated with increased proportion of CD56(+) T cells in peripheral blood. Ophthalmology 120:2310-2316. doi:10.1016/j.ophtha.2013.04. 014

239. Koreck A, Suranyi A, Szony BJ, Farkas A, Bata-Csorgo Z, Kemeny L, Dobozy A (2002) CD3+CD56+NK T cells are significantly decreased in the peripheral blood of patients with psoriasis. Clin Exp Immunol 127:176-182. doi:10.1046/j.13652249.2002.01721.x

240. Ahn JK, Chung H, Lee DS, Yu YS, Yu HG (2005) CD8brightCD56+ $\mathrm{T}$ cells are cytotoxic effectors in patients with active Behcet's uveitis. J Immunol 175:6133-6142. doi:10. 4049/jimmunol.175.9.6133

241. Michel JJ, Turesson C, Lemster B, Atkins SR, Iclozan C, Bongartz T, Wasko MC, Matteson EL, Vallejo AN (2007) CD56-expressing $\mathrm{T}$ cells that have features of senescence are expanded in rheumatoid arthritis. Arthritis Rheum 56:43-57. doi:10.1002/art.22310

242. Li WX, Pan HF, Hu JL, Wang CZ, Zhang N, Li J, Li XP, Xu JH, Ye DQ (2010) Assay of T- and NK-cell subsets and the expression of NKG2A and NKG2D in patients with new-onset systemic lupus erythematosus. Clin Rheumatol 29:315-323. doi:10.1007/s10067-009-1322-9

243. Penfold PL, Provis JM, Furby JH, Gatenby PA, Billson FA (1990) Autoantibodies to retinal astrocytes associated with agerelated macular degeneration. Graefes Arch Clin Exp Ophthalmol 228:270-274. doi:10.1007/BF00920033

244. Gu X, Meer SG, Miyagi M, Rayborn ME, Hollyfield JG, Crabb JW, Salomon RG (2003) Carboxyethylpyrrole protein adducts and autoantibodies, biomarkers for age-related macular degeneration. J Biol Chem 278:42027-42035. doi:10.1074/jbc. M305460200

245. Patel N, Ohbayashi M, Nugent AK, Ramchand K, Toda M, Chau KY, Bunce C, Webster A, Bird AC, Ono SJ, Chong V (2005) Circulating anti-retinal antibodies as immune markers in agerelated macular degeneration. Immunology 115:422-430. doi:10.1111/j.1365-2567.2005.02173.x

246. Dhillon B, Wright AF, Tufail A, Pappworth I, Hayward C, Moore I, Strain L, Kavanagh D, Barlow PN, Herbert AP, Schmidt CQ, Armbrecht AM, Laude A, Deary IJ, Staniforth SJ, Holmes LV, Goodship TH, Marchbank KJ (2010) Complement factor $\mathrm{H}$ autoantibodies and age-related macular degeneration. Invest Ophthalmol Vis Sci 51:5858-5863. doi:10.1167/iovs.095124

247. Morohoshi K, Ohbayashi M, Patel N, Chong V, Bird AC, Ono SJ (2012) Identification of anti-retinal antibodies in patients with age-related macular degeneration. Exp Mol Pathol 93:193-199. doi:10.1016/j.yexmp.2012.03.007

248. Camelo S (2014) Potential sources and roles of adaptive immunity in age-related macular degeneration: Shall we rename AMD into autoimmune macular disease? Autoimmune Dis 2014:532487. doi: $10.1155 / 2014 / 532487$

249. Bergstrom I, Backteman K, Lundberg A, Ernerudh J, Jonasson L (2012) Persistent accumulation of interferon-gamma-producing $\mathrm{CD} 8+\mathrm{CD} 56+\mathrm{T}$ cells in blood from patients with coronary artery disease. Atherosclerosis 224:515-520. doi:10.1016/j. atherosclerosis.2012.07.033

250. Klein R, Cruickshanks KJ, Myers CE, Sivakumaran TA, Iyengar SK, Meuer SM, Schubert CR, Gangnon RE, Klein BE (2013) The relationship of atherosclerosis to the 10-year cumulative incidence of age-related macular degeneration: the Beaver Dam studies. Ophthalmology 120:1012-1019. doi:10.1016/j.ophtha. 2012.11.003

251. Guymer RH, Tao LW, Goh JK, Liew D, Ischenko O, Robman LD, Aung K, Cipriani T, Cain M, Richardson AJ, Baird PN, Langham R (2011) Identification of urinary biomarkers for agerelated macular degeneration. Invest Ophthalmol Vis Sci 52:4639-4644. doi:10.1167/iovs.10-7120

252. Reynolds R, Hartnett ME, Atkinson JP, Giclas PC, Rosner B, Seddon JM (2009) Plasma complement components and activation fragments: associations with age-related macular degeneration genotypes and phenotypes. Invest Ophthalmol Vis Sci 50:5818-5827. doi:10.1167/iovs.09-3928

253. Hecker LA, Edwards AO, Ryu E, Tosakulwong N, Baratz KH, Brown WL, Charbel Issa P, Scholl HP, Pollok-Kopp B, SchmidKubista KE, Bailey KR, Oppermann M (2010) Genetic control of the alternative pathway of complement in humans and agerelated macular degeneration. Hum Mol Genet 19:209-215. doi: $10.1093 / \mathrm{hmg} / \mathrm{ddp} 472$

254. Stanton CM, Yates JR, den Hollander AI, Seddon JM, Swaroop A, Stambolian D, Fauser S, Hoyng C, Yu Y, Atsuhiro K, Branham K, Othman M, Chen W, Kortvely E, Chalmers K, Hayward C, Moore AT, Dhillon B, Ueffing M, Wright AF (2011) Complement factor D in age-related macular degeneration. Invest Ophthalmol Vis Sci 52:8828-8834. doi:10.1167/ iovs.11-7933 
255. Silva AS, Teixeira AG, Bavia L, Lin F, Velletri R, Belfort R Jr, Isaac L (2012) Plasma levels of complement proteins from the alternative pathway in patients with age-related macular degeneration are independent of Complement Factor $\mathrm{H}$ $\operatorname{Tyr}(4)(0)(2) H i s$ polymorphism. Mol Vis 18:2288-2299

256. Haas P, Aggermann T, Nagl M, Steindl-Kuscher K, Krugluger W, Binder S (2011) Implication of CD21, CD35, and CD55 in the pathogenesis of age-related macular degeneration. Am J Ophthalmol 152(396-399):e1. doi:10.1016/j.ajo.2011.02.017

257. Singh A, Faber C, Falk M, Nissen MH, Hviid TV, Sorensen TL (2012) Altered expression of CD46 and CD59 on leukocytes in neovascular age-related macular degeneration. Am J Ophthalmol 154(193-199):e2. doi:10.1016/j.ajo.2012.01.036

258. Cipriani V, Matharu BK, Khan JC, Shahid H, Stanton CM, Hayward C, Wright AF, Bunce C, Clayton DG, Moore AT, Yates JR (2012) Genetic variation in complement regulators and susceptibility to age-related macular degeneration. Immunobiology 217:158-161. doi:10.1016/j.imbio.2011.09.002

259. Cao S, Ko A, Partanen M, Pakzad-Vaezi K, Merkur AB, Albiani DA, Kirker AW, Wang A, Cui JZ, Forooghian F, Matsubara JA (2013) Relationship between systemic cytokines and complement factor $\mathrm{H} \mathrm{Y} 402 \mathrm{H}$ polymorphism in patients with dry agerelated macular degeneration. Am $\mathrm{J}$ Ophthalmol 156:1176-1183. doi:10.1016/j.ajo.2013.08.003

260. An E, Gordish-Dressman H, Hathout Y (2008) Effect of TNFalpha on human ARPE-19-secreted proteins. Mol Vis 14:2292-2303

261. Leung KW, Barnstable CJ, Tombran-Tink J (2009) Bacterial endotoxin activates retinal pigment epithelial cells and induces their degeneration through IL-6 and IL-8 autocrine signaling. Mol Immunol 46:1374-1386. doi:10.1016/j.molimm.2008.12. 001

262. Lee IT, Liu SW, Chi PL, Lin CC, Hsiao LD, Yang CM (2015) TNF-alpha mediates PKCdelta/JNK1/2/c-Jun-dependent monocyte adhesion via ICAM-1 induction in human retinal pigment epithelial cells. PLoS One 10:e0117911. doi:10.1371/journal. pone.0117911

263. Oh H, Takagi H, Takagi C, Suzuma K, Otani A, Ishida K, Matsumura M, Ogura Y, Honda Y (1999) The potential angiogenic role of macrophages in the formation of choroidal neovascular membranes. Invest Ophthalmol Vis Sci 40:1891-1898

264. Cousins SW, Espinosa-Heidmann DG, Csaky KG (2004) Monocyte activation in patients with age-related macular degeneration: a biomarker of risk for choroidal neovascularization? Arch Ophthalmol 122:1013-1018. doi:10.1001/ archopht.122.7.1013

265. Liu B, Faia L, Hu M, Nussenblatt RB (2010) Pro-angiogenic effect of IFNgamma is dependent on the $\mathrm{PI} 3 \mathrm{~K} / \mathrm{mTOR} /$ translational pathway in human retinal pigmented epithelial cells. Mol Vis 16:184-193

266. Juel HB, Faber C, Udsen MS, Folkersen L, Nissen MH (2012) Chemokine expression in retinal pigment epithelial ARPE-19 cells in response to coculture with activated $\mathrm{T}$ cells. Invest Ophthalmol Vis Sci 53:8472-8480. doi:10.1167/iovs.12-9963

267. Faber C, Jehs T, Juel HB, Singh A, Falk MK, Sorensen TL, Nissen MH (2015) Early and exudative age-related macular degeneration is associated with increased plasma levels of soluble TNF receptor II. Acta Ophthalmol 93:242-247. doi:10. $1111 /$ aos. 12581

268. Chau KY, Sivaprasad S, Patel N, Donaldson TA, Luthert PJ, Chong NV (2008) Plasma levels of matrix metalloproteinase-2 and -9 (MMP-2 and MMP-9) in age-related macular degeneration. Eye (Lond) 22:855-859. doi:10.1038/sj.eye.6702722

269. Seddon JM, George S, Rosner B, Rifai N (2005) Progression of age-related macular degeneration: prospective assessment of C-reactive protein, interleukin 6, and other cardiovascular biomarkers. Arch Ophthalmol 123:774-782. doi:10.1001/ archopht.123.6.774

270. Mooijaart SP, Koeijvoets KM, Sijbrands EJ, Daha MR, Westendorp RG (2007) Complement Factor H polymorphism $\mathrm{Y} 402 \mathrm{H}$ associates with inflammation, visual acuity, and cardiovascular mortality in the elderly population at large. Exp Gerontol 42:1116-1122. doi:10.1016/j.exger.2007.08.001

271. Klein R, Myers CE, Cruickshanks KJ, Gangnon RE, Danforth LG, Sivakumaran TA, Iyengar SK, Tsai MY, Klein BE (2014) Markers of inflammation, oxidative stress, and endothelial dysfunction and the 20-year cumulative incidence of early agerelated macular degeneration: the Beaver Dam Eye Study. JAMA Ophthalmol 132:446-455. doi:10.1001/jamaophthalmol. 2013.7671

272. Mo FM, Proia AD, Johnson WH, Cyr D, Lashkari K (2010) Interferon gamma-inducible protein-10 (IP-10) and eotaxin as biomarkers in age-related macular degeneration. Invest Ophthalmol Vis Sci 51:4226-4236. doi:10.1167/iovs.09-3910

273. Hong T, Tan AG, Mitchell P, Wang JJ (2011) A review and meta-analysis of the association between $\mathrm{C}$-reactive protein and age-related macular degeneration. Surv Ophthalmol 56:184-194. doi:10.1016/j.survophthal.2010.08.007

274. Mitta VP, Christen WG, Glynn RJ, Semba RD, Ridker PM, Rimm EB, Hankinson SE, Schaumberg DA (2013) C-reactive protein and the incidence of macular degeneration: pooled analysis of 5 cohorts. JAMA Ophthalmol 131:507-513. doi:10. 1001/jamaophthalmol.2013.2303

275. Yip JL, Khawaja AP, Chan MP, Broadway DC, Peto T, Tufail A, Luben R, Hayat S, Bhaniani A, Wareham NJ, Khaw KT, Foster PJ (2015) Cross sectional and longitudinal associations between cardiovascular risk factors and age related macular degeneration in the EPIC-Norfolk eye study. PLoS One 10:e0132565. doi:10.1371/journal.pone.0132565

276. Smith W, Mitchell P, Leeder SR, Wang JJ (1998) Plasma fibrinogen levels, other cardiovascular risk factors, and age-related maculopathy: the Blue Mountains Eye Study. Arch Ophthalmol 116:583-587. doi:10.1001/archopht.116.5.583

277. Schaumberg DA, Christen WG, Buring JE, Glynn RJ, Rifai N, Ridker PM (2007) High-sensitivity C-reactive protein, other markers of inflammation, and the incidence of macular degeneration in women. Arch Ophthalmol 125:300-305. doi:10.1001/ archopht.125.3.300

278. Jiang S, Moriarty-Craige SE, Li C, Lynn MJ, Cai J, Jones DP, Sternberg P (2008) Associations of plasma-soluble fas ligand with aging and age-related macular degeneration. Invest Ophthalmol Vis Sci 49:1345-1349. doi:10.1167/iovs.07-0308

279. Sharma NK, Prabhakar S, Gupta A, Singh R, Gupta PK, Gupta PK, Anand A (2012) New biomarker for neovascular age-related macular degeneration: eotaxin-2. DNA Cell Biol 31:1618-1627. doi:10.1089/dna.2012.1786

280. Juel HB, Faber C, Munthe-Fog L, Bastrup-Birk S, ReesePetersen AL, Falk MK, Singh A, Sorensen TL, Garred P, Nissen MH (2015) Systemic and ocular long Pentraxin 3 in patients with age-related macular degeneration. PLoS One 10:e0132800. doi:10.1371/journal.pone.0132800 